\title{
Marine Biodiversity in Temperate Western Australia: Multi-Taxon Surveys of Minden and Roe Reefs
}

\author{
Zoe Richards ${ }^{1}$ * , Lisa Kirkendale ${ }^{1}$, Glenn Moore ${ }^{1}$, Andrew Hosie ${ }^{1}$, John Huisman ${ }^{2}$, \\ Monika Bryce ${ }^{1}$, Loisette Marsh ${ }^{1}$, Clay Bryce ${ }^{1}$, Ana Hara ${ }^{1}$, Nerida Wilson ${ }^{1}$, Susan Morrison ${ }^{1}$, \\ Oliver Gomez $^{1}$, Jenelle Ritchie ${ }^{1}$, Corey Whisson ${ }^{1}$, Mark Allen ${ }^{1}$, Lee Betterridge ${ }^{1}$, \\ Courtney Wood ${ }^{1}$, Hugh Morrison ${ }^{1}$, Mark Salotti ${ }^{1}$, Glad Hansen ${ }^{1}$, Shirley Slack-Smith ${ }^{1}$ and \\ Jane Fromont 1 \\ 1 Department of Aquatic Zoology, Western Australian Museum, Locked Bag 49, Welshpool DC, \\ Western Australia 6986, Australia; lisa.kirkendale@museum.wa.gov.au (L.K.); \\ glenn.moore@museum.wa.gov.au (G.M.); andrew.hosie@museum.wa.gov.au (A.Ho.); \\ monika.bryce@museum.wa.gov.au (M.B.); clay.bryce@museum.wa.gov.au (C.B.); \\ ana.hara@museum.wa.gov.au (A.Ha.); nerida.wilson@museum.wa.gov.au (N.W.); \\ oliver.gomez@museum.wa.gov.au (O.G.); jenelle.ritchie@museum.wa.gov.au (J.R.); \\ corey.whisson@museum.wa.gov.au (C.Wh.); mark.allen@museum.wa.gov.au (M.A.); \\ shells@seashells.net.au (H.M.); mark.salotti@museum.wa.gov.au (M.S.); gladh@iinet.net.au (G.H.); \\ shirley.slacksmith@museum.wa.gov.au (S.S.-S.); jane.fromont@museum.wa.gov.au (J.F.) \\ 2 Western Australian Herbarium, Science Division, Department of Parks and Wildlife, Locked Bag 104, \\ Bentley Delivery Centre, Western Australia 6983, Australia; John.Huisman@DPaW.wa.gov.au \\ * Correspondence: zoe.richards@museum.wa.gov.au; Tel.: +618-9212-3872
}

Academic Editor: Michael Wink

Received: 24 December 2015; Accepted: 17 March 2016; Published: 24 March 2016

Abstract: A growing body of evidence indicates that temperate marine ecosystems are being tropicalised due to the poleward extension of tropical species. Such climate mediated changes in species distribution patterns have the potential to profoundly alter temperate communities, as this advance can serve to push temperate taxa, many of which are southern Australian endemics, southward. These changes can lead to cascading effects for the biodiversity and function of coastal ecosystems, including contraction of ranges/habitats of sensitive cool water species. Hence there is growing concern for the future of Australia's temperate marine biodiversity. Here we examine the diversity and abundance of marine flora and fauna at two reefs near Perth's metropolitan area-Minden Reef and Roe Reef. We report the presence of 427 species of marine flora and fauna from eight taxon groups occurring in the Perth metropolitan area; at least three species of which appear to be new to science. Our data also extends the known range of 15 species, and in numerous instances, thousands of kilometres south from the Kimberley or Pilbara and verifies that tropicalisation of reef communities in the Perth metropolitan area is occurring. We report the presence of 24 species endemic to south-west Australia that may be at risk of range contractions with continued ocean warming. The results of these surveys add to our knowledge of local nearshore marine environments in the Perth metropolitan area and support the growing body of evidence that indicates a diverse and regionally significant marine fauna occurs in temperate Western Australia. Regular, repeated survey work across seasons is important in order to thoroughly document the status of marine biodiversity in this significant transition zone.

Keywords: baseline; climate change; distribution; diversity; endemic; Perth; tropicalisation

\section{Introduction}

The Earth's climate is changing and observed climate changes are causing a wide array of impacts [1]. In marine systems, poleward shifts of many tropical species within the cnidarians, fishes, 
molluscs, echinoderms and crustaceans have been attributed to climate change [2-12]. Additionally, behaviours such as breeding and migration are expected to respond to climate change [13]. On a global scale, the upper $75 \mathrm{~m}$ of the oceans have warmed by $0.11(0.09$ to 0.13$){ }^{\circ} \mathrm{C}$ per decade over the period 1971 to 2010, and the latest projections indicate warming will continue in all oceans across all depths [14]. As a result, further range shifts and changes to biological patterns and processes are predicted to occur across a wide range of taxa $[15,16]$.

Temperate marine habitats can provide climate refuges for tropical species and potentially offset temperature induced local extinctions [7]; however they may also be negatively impacted at the ecosystem level. There is growing concern that the tropicalisation of cool water marine communities will lead to the loss of some of Australia's unique temperate marine biodiversity. Although Australian cool waters have lower species diversity than northern tropical waters, they harbor much higher proportions of endemic species. The south-west region of Western Australia (WA) is part of the southern temperate faunal province, a region extending across the entire southern coast of Australia and into southern New South Wales, and includes Tasmania and New Zealand [17]. This region has high levels of endemism estimated to be between $75 \%$ [18] and $95 \%[19,20]$ for molluscs. These high endemic percentages are reflected across the entire southern Australian province in many other marine groups including fishes (85\%); echinoderms (31\%), sponges (56\%) and macroalgae (50\%) [21,22].

Southern Australia has experienced pronounced increases in ocean temperatures [14] and coastal waters in south-western Australia have also warmed appreciably, increasing by $0.013^{\circ} \mathrm{C}$. year ${ }^{-1}$ since 1951 [23]. Any climate induced changes in species abundance and/or distribution patterns may have deleterious impacts on temperate taxa. Attrition of taxonomic diversity has already been observed in association with the poleward expansion of the barren-forming sea urchin, Centrostephanus rodgersii from NSW southward to eastern Tasmania [3], where a minimum of 150 taxa associated with macroalgal beds are estimated to have been lost [24]. Tropicalisation of temperate reef communities can also lead to deleterious shifts in community structure [15]. Of paramount concern are the intrusions of tropical herbivorous fishes, which can lead to overgrazing and the loss of foundation species such as canopy-forming algae [25-27]. Climate induced changes are also implicated in impacts to the abundance and recruitment dynamics of commercially important species such as the Panulirus cygnus (Western Rock Lobster) [28].

Furthermore, warming waters may facilitate the establishment, spread and impact, of invasive exotic species in temperate marine systems [29]. For example, the exotic Carcinus maenas (European green shore crab), a predator in intertidal and shallow subtidal habitats, has extended its range from Victoria into Tasmania in response to increasing ocean temperatures and the strengthening of the East Australia Current [30]. Dosidicus gigas (Humboldt or Jumbo squid) was rarely observed beyond San Diego a decade ago, but now has been observed as far north as Alaska [31]. This range shift has been attributed to climate change and an increase in areas referred to as "dead zones", which the squid are able to exploit due to low oxygen tolerance. Fisheries scientists are monitoring this voracious, top predator species, and where schooling populations are high, impacts to prey species are expected to be significant [32].

Climate is not, however, the only reason for change in marine environments, other factors including population growth, urbanisation, pollution, overfishing and shipping all interact to influence the composition and structure of marine communities $[33,34]$. In order to fully understand the extent of changes to species distribution and abundance patterns, and to effectively manage and conserve temperate resources, quantitative baseline data are urgently required. Western Australia provides an ideal natural laboratory to monitor and examine the effect of climate change on marginal reef communities [35]. The State occupies roughly one third of the Australian continent, and has $24,000 \mathrm{~km}$ of continuous north-south aligned coastline [36] spanning nearly $22^{\circ}$ of latitude [37]. In contrast to the east coast of Australia, where a similar expanse of coastline is split across three separate States (Queensland, New South Wales and Victoria), potentially complicating effective monitoring due to the need for coordination among jurisdictions, in WA marine resource monitoring and management efforts 
are coordinated by multiple partner agencies within a single jurisdiction. One third of the coast lies in the tropics (Pilbara and Kimberley coasts, $12^{\circ}-23.5^{\circ} \mathrm{S}$ ), and there is also substantial subtropical habitat (Shark Bay, Houtman Abrolhos Islands to Jurien Bay $23.5^{\circ}-31^{\circ} \mathrm{S}$ ), shifting to temperate coastline (Perth to Esperance, $32^{\circ}-34^{\circ} \mathrm{S}$ ) in the south.

Temperate reefs near Perth $\left(\sim 32^{\circ} \mathrm{S}\right)$ occur in the transition zone between subtropical and temperate habitats. In situ temperature measurements at a monitoring station off Rottnest Island indicate that the mean ocean temperature has increased $\sim 0.6^{\circ} \mathrm{C}$ over the past five decades [23]. While reefs in the Perth metropolitan area occur well outside the tropics and do not form coral reefs, they can support a high level of hard coral cover (e.g., 72.5\% coral cover was recorded at Hall Bank) [38]. To date, 25 scleractinian coral species have been recorded in the vicinity of Perth and Rottnest Island [37], and this region forms the southernmost boundary for half of these species. Rottnest Island also forms the southernmost boundaries for many reef fish species including twenty that were first observed at the island in 1991 [39]. The marine crustacean fauna of Rottnest also has a strong tropical influence with 39\% being Indo-West Pacific species and $48 \%$ being southern Australian endemics [40]. The flora and fauna of Rottnest Island were examined in detail in the 1990s [41-44] and these volumes provide a detailed qualitative baseline of the many marine taxa, however, comprehensive biodiversity assessments for some groups (e.g., molluscs, sponges) are still lacking.

Roe Reef, Rottnest Island and Minden Reef, Fremantle are two reef systems that occur in close proximity to the Perth metropolitan area. To our knowledge Minden Reef has never been formally surveyed, and comprehensive surveys of benthic fauna at Roe Reef are lacking, hence no quantitative information about the faunal and floral composition of these reefs is available. In order to fill this knowledge gap, and to provide a baseline of information for the level of benthic cover and diversity within eight taxon groups (hard corals, soft corals, sponges, molluscs, crustaceans, echinoderms, fishes, algae), we undertook the first quantitative diversity assessments of these two locations in 2013 and 2014. Furthermore the Western Australian Museum database, Ozcam, Atlas of Living Australia, WORMS and other databases (where relevant) were queried to examine the known distribution for the flora and fauna we recorded in order to determine the extent of tropicalisation occurring in our study area. Here we report the findings of these baseline surveys, which will assist detection of future changes in community composition and structure at these locations.

\section{Results}

A total of 427 species were recorded from Minden and Roe Reefs (Table 1 and Table S1). A total of 188 species were recorded from Minden Reef (excludes marine plants), 128 of which were recorded at Site 1 and 129 at Site 2 . A total of 287 species were recorded at Roe Reef, 207 of which were at Site 1 and 203 at Site 2 .

Table 1. Summary of species diversity and collections from surveys of Minden and Roe Reefs.

\begin{tabular}{|c|c|c|c|c|c|c|c|c|c|}
\hline & Hard Corals & Octocorals & Sponges & Molluscs & Crusta & hinoderms & Fishes & Marine Plants & Total \\
\hline \multirow{3}{*}{$\begin{array}{l}\text { Minden Reef } \\
\text { \# Species } \\
\text { \# Specimens } \\
\text { collected } \\
\text { \# Visual } \\
\text { Records }\end{array}$} & 12 & 4 & 27 & 48 & 34 & 16 & 46 & NA & 188 \\
\hline & 27 & 7 & 44 & $27^{*}$ & 157 & 17 & 0 & NA & $252^{\wedge}$ \\
\hline & 2 & 0 & 2 & 282 & 0 & 0 & 46 & NA & 332 \\
\hline \multirow{3}{*}{$\begin{array}{l}\text { Roe Reef } \\
\text { \# Species } \\
\text { \# Specimens } \\
\text { collected } \\
\text { \# Visual } \\
\text { Records }\end{array}$} & 9 & 4 & 48 & 40 & 45 & 16 & 56 & 69 & 287 \\
\hline & 22 & 4 & 38 & 58 * & 140 & 18 & 0 & 2 & $224^{\wedge}$ \\
\hline & 0 & 0 & 12 & 10 & 1 & 0 & 56 & 67 & 146 \\
\hline
\end{tabular}

${ }^{*}$ Number of specimens collected may represent specimen lots; ‘ excludes specimen lots. 


\subsection{Benthic Cover}

The two reefs were dominated by algae with hard coral and other occasional benthic invertebrates along the point-intercept transects. Site 1 on the northern side of Minden Reef was dominated by turf algae $(57.5 \% \pm 12 \%$ ) and kelp (Ecklonia radiata, $24.3 \% \pm 14.5 \%$ ) (Figure 1). A variety of other types of brown, green and red algae also contributed an additional $4 \%$ benthic cover. Hard corals, sponges and ascidians contributed to less than $4 \%$ of the combined benthic cover. Site 2 on the southern side of Minden Reef was dominated by seagrasses ( $49 \% \pm 12.8 \%)$, especially Posidonia and Halophila. Hard coral cover peaked at $6 \%( \pm 2.1 \%)$ at this site. Intermittent soft coral colonies and individual sponge were also encountered and were minor contributors to the benthic cover $(<5 \%$ combined).

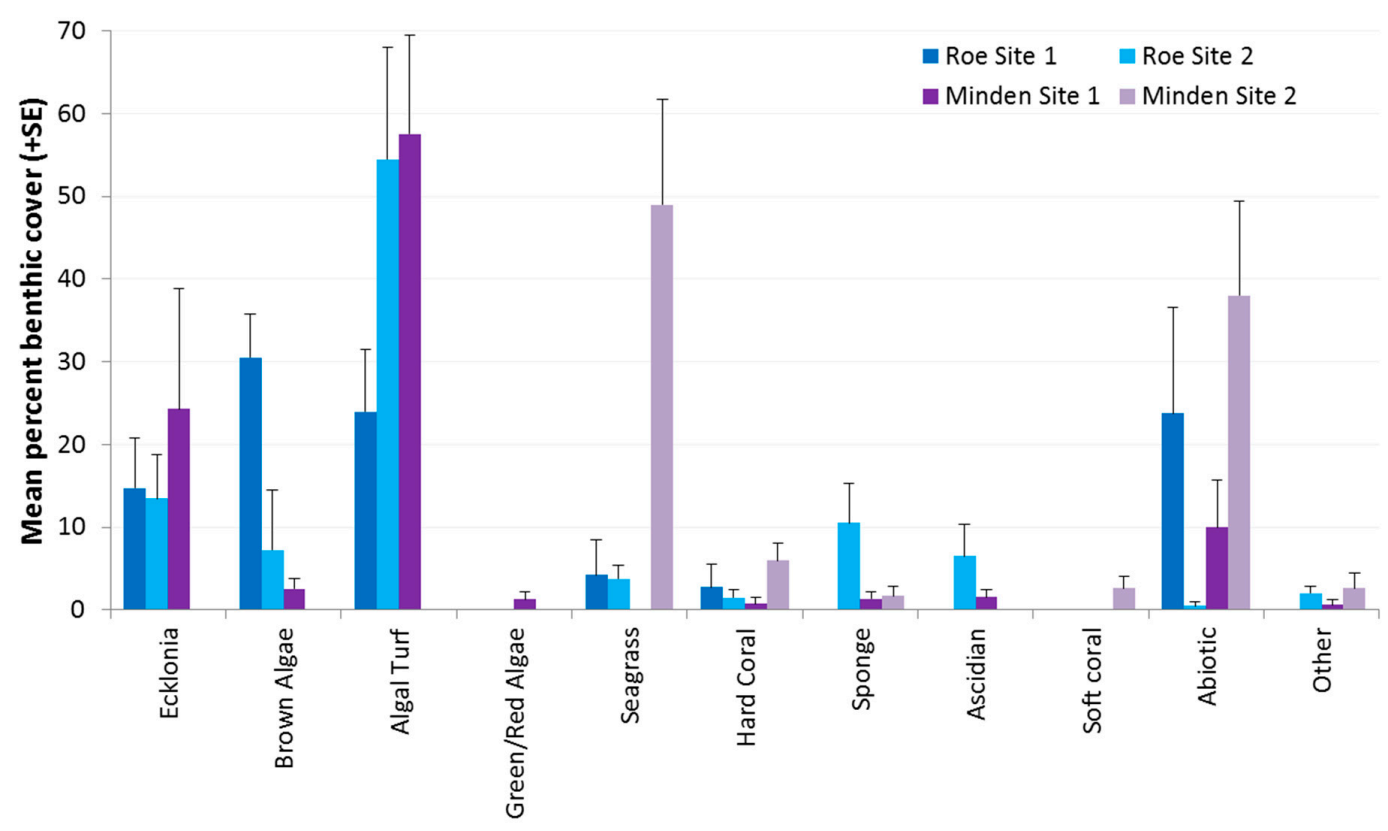

Figure 1. Mean cover (+SE) of dominant benthic organisms at the four survey sites. "Abiotic" includes sand, rock and rubble; "Other" includes seastars, tubeworms, zoanthids and bryozoans.

Site 1 on the eastern side of Roe Reef was substantially deeper than the other sites surveyed (20-25 $\mathrm{m}$ as opposed to 8-12 $\mathrm{m}$ ). The benthos at this depth was dominated by various types of brown algae $(30.5 \% \pm 5.3 \%)$. Ecklonia radiata contributed $14.8 \%( \pm 6 \%)$ to the level of macro-algal cover (Figure 1). Algal turf constituted $24 \% \pm 7.5 \%$ of the benthos and hard corals were intermittently encountered, accounting for $2.8 \%( \pm 2.8 \%)$ of the benthic cover. The abiotic substrate, which included limestone sediment, accounted for a further $24 \%( \pm 12.8 \%)$ of the benthic cover. Site 2 on the central part of Roe Reef was low in profile and the reef was wave swept with well-developed surge channels. As a consequence, algal turf was the major contributor to the benthic cover $(55 \% \pm 13.5 \%)$. Ecklonia radiata also accounted for $13.5 \%( \pm 5.3 \%)$ of the benthic cover. Sponges covered $10.5 \%( \pm 4.9 \%)$ of the benthos and the ascidian, Herdmania momus, was also recorded on the point-intercept transects.

\subsection{Hard Corals}

Sixteen species of scleractinian coral and one species of stylasterid coral were recorded from the two reefs. At Minden Reef, 219 colonies were encountered at the two survey sites. From these, 27 skeletal samples were collected and 18 molecular samples. Laboratory examination of the skeletal specimens confirmed the existence of 12 hard coral species (Table S1). At Roe Reef a total of 60 colonies of hard coral were encountered at the two sites. From these, 19 skeletal samples were collected and 22 molecular samples. Laboratory examination of the skeletal specimens confirmed the existence of nine hard coral species (Table S1). 
The composition of the coral community composition at both Minden Reef sites were similar, however a higher number of species and biomass of corals was recorded at Site 2 (Table S1). The Minden Reef community was dominated by Coelastrea aspera, Plesiastrea versipora and Paragoniastrea australiensis (Figure 2). At Roe Reef despite the two sites being very close together, community composition differed markedly and there was a higher abundance of hard corals at Site 2. Only one species (Montipora mollis) was encountered at both sites. Site 1 was dominated by Coscinaraea marshae, Coscinaraea moneilli and Montipora mollis, while Site 2 was dominated by Plesiastrea versipora, Pocillopora damicornis and Montipora mollis (Table S1). The Roe Reef community differed markedly from that recorded at nearby Minden Reef because no Dipsastraea, Symphyllia or Goniopora species were recorded at Roe Reef and no Pocillopora or Montipora species were encountered at Minden Reef. Furthermore, the biomass of corals at Minden Reef was approximately three times higher than that recorded at Roe Reef.
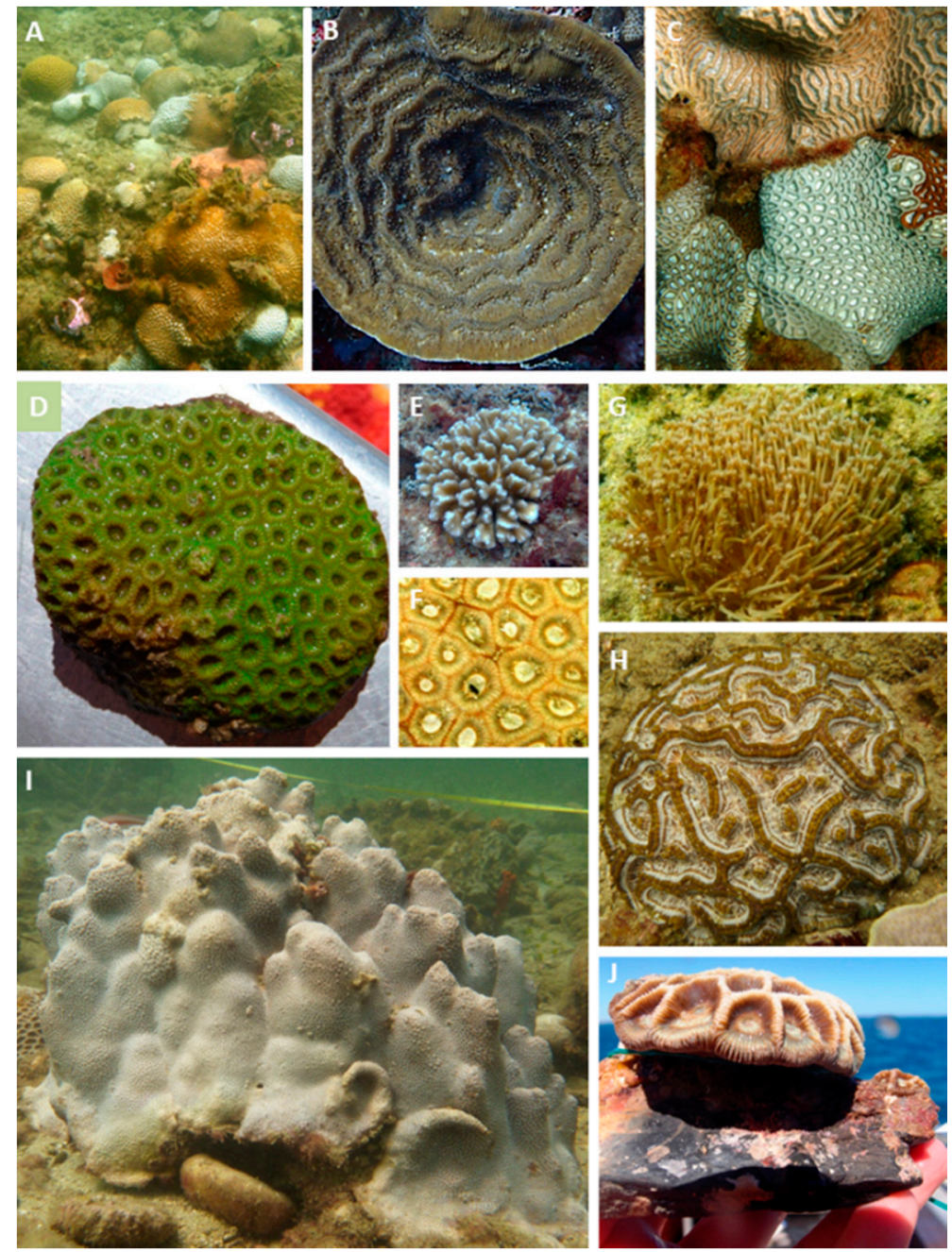

Figure 2. Scleractinian corals of Minden and Roe Reefs. (A). Merulinid corals dominate the community; (B). Coscinaraea marshae; (C). Paragoniastrea australensis (top) and Coelastrea aspera (bottom); (D). A bright green morph of Plesiastrea versipora; (E). Pocillopora damicornis; (F). Favites rotundata, a new record from this latitude; (G). Goniopora pendulus; (H). Symphyllia wilsonii; (I). A large submassive colony of Cyphastrea serealia; $(\mathbf{J})$. Coelastrea aspera growing on a piece of coal.

\subsection{Soft Corals (Octocorals)}

Species richness across the two reefs was low with only eight species recorded. However, the species composition of the two reefs was distinct. Four species of soft coral were identified at each 
location (Table S1). At Minden Reef a total of 34 colonies were encountered. Alertigorgia mjöbergi was the dominant soft coral species and the only species recorded at both Minden Reef sites. Single colonies of two other species (Euplexaura sp. and Capnella gaboensis), were encountered and collected. Capnella gaboensisis is known to be abundant and widely distributed in temperate Australian waters [45]. This is in contrast to the octocoral species Alertigorgia mjöbergi, which grows almost exclusively in littoral tropical waters. The occurrence of Alertigorgia mjöbergi at Minden Reef appears to be the southernmost record for this species.

Sixteen soft coral colonies were encountered at Roe Reef. Two sea fans, a bright red Mopsella sp. and a white Melithaea sp., were collected from both sites while Sinularia sp. and Skamnarium complanatum (Figure 3) were only collected at Site 2. The sea fans were growing under small overhangs and caves, while the other two species were found on top of the reef. Skamnarium complanatum appears to be a rare species and endemic to the Perth region. It was described from Rottnest Island by Verseveldt [46] from half a colony collected at Parakeet Bay, and later reported and redescribed by Alderslade [47] from Thomson Bay. Additional samples were collected in 1979 from shallow waters off Whitfords Beach near Hillarys Marina. The small colony collected at Roe Reef consists of a stalk and a slightly concave, semicircular disc, which becomes dish shaped when the colony is tightly contracted (Figure 3). The polyps are confined to the colony summit. In situ the summit is blue-grey and the polyps are yellowish.
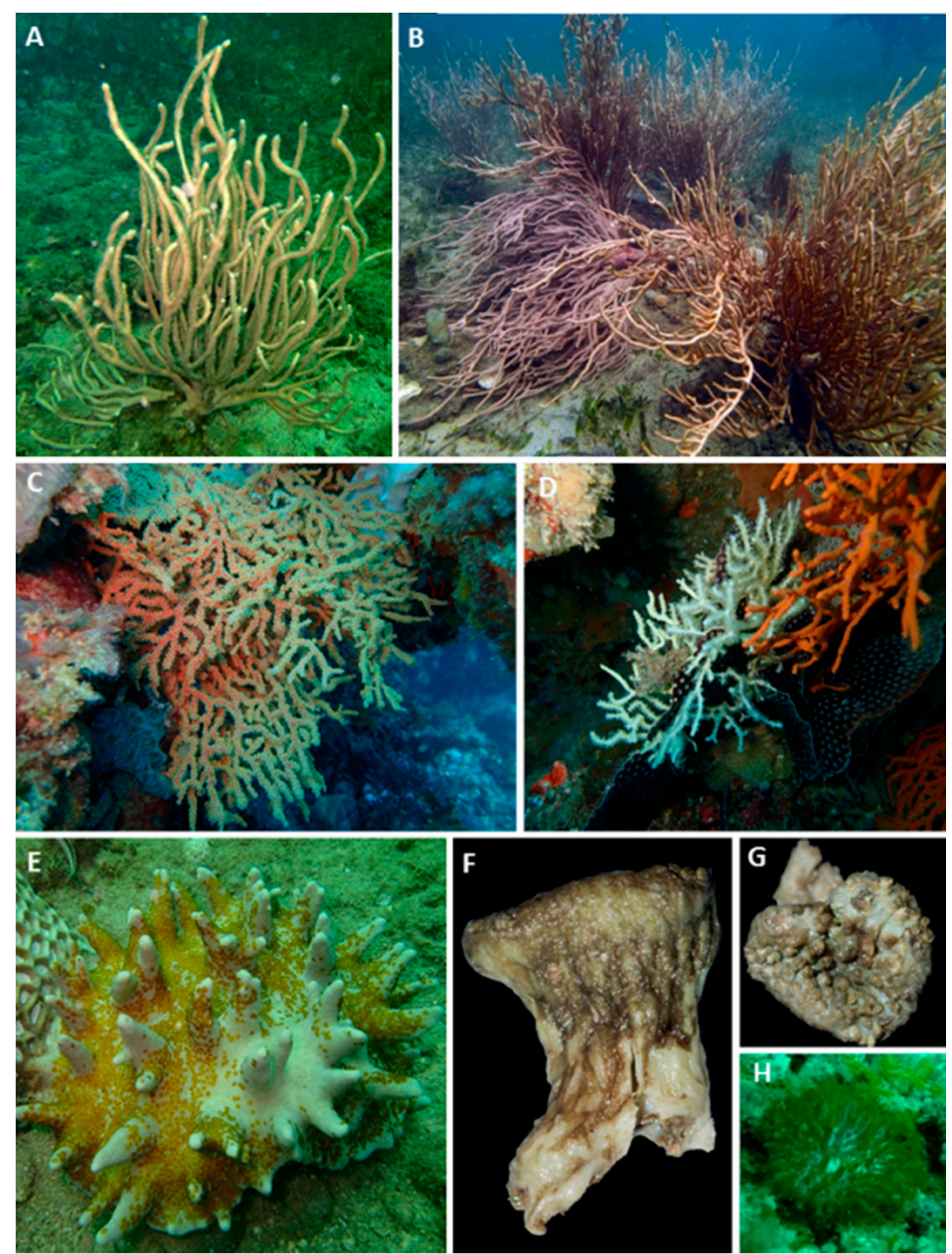

Figure 3. Octocorallia of Minden and Roe Reefs. (A,B). The dominant octocoral Alertigorgia mjöbergi; (C,D). Sea fans belonging to the family Melithaeidae; (E). large colony of Sinularia sp.; $(\mathbf{F}, \mathbf{G})$. Skamnarium complanatum on deck; (H). Skamnarium complanatum in situ. 


\subsection{Sponges}

A combined total of 67 species of sponges were identified at the two reef locations. However, the composition of the sponge communities varied considerably within and between reefs. At Minden Reef, Site 2 had higher species richness (22 species) than Site 1 (13 species); whilst at Roe Reef, 23 species were recorded at Site 1 , and 33 species were recorded at Site 2 . No species were recorded at all four survey sites and only three (Cymbastela marshae, Sycon sp. MR1; Leucetta prolifera) were recorded at both reefs (Table S1).

Twenty seven sponge species were identified from the two Minden Reef sites. Three of these were from the class Calcarea and the other 24 were Demospongiae. The most speciose order was the Poecilosclerida with six species recorded, followed by the Haplosclerida and Dictyoceratida with five species each. Chondrosia sp. MR1 was the most abundant species with 103 individuals counted from both sites (Figure 4). Ircinia sp. MR1 and Spheciospongia papillosa were also in high abundance at both sites (44 and 23 individuals, respectively). A further seven species had 10 or more individuals, while the remaining 17 species were rare with nine or fewer individuals counted at both sites (Table S1).
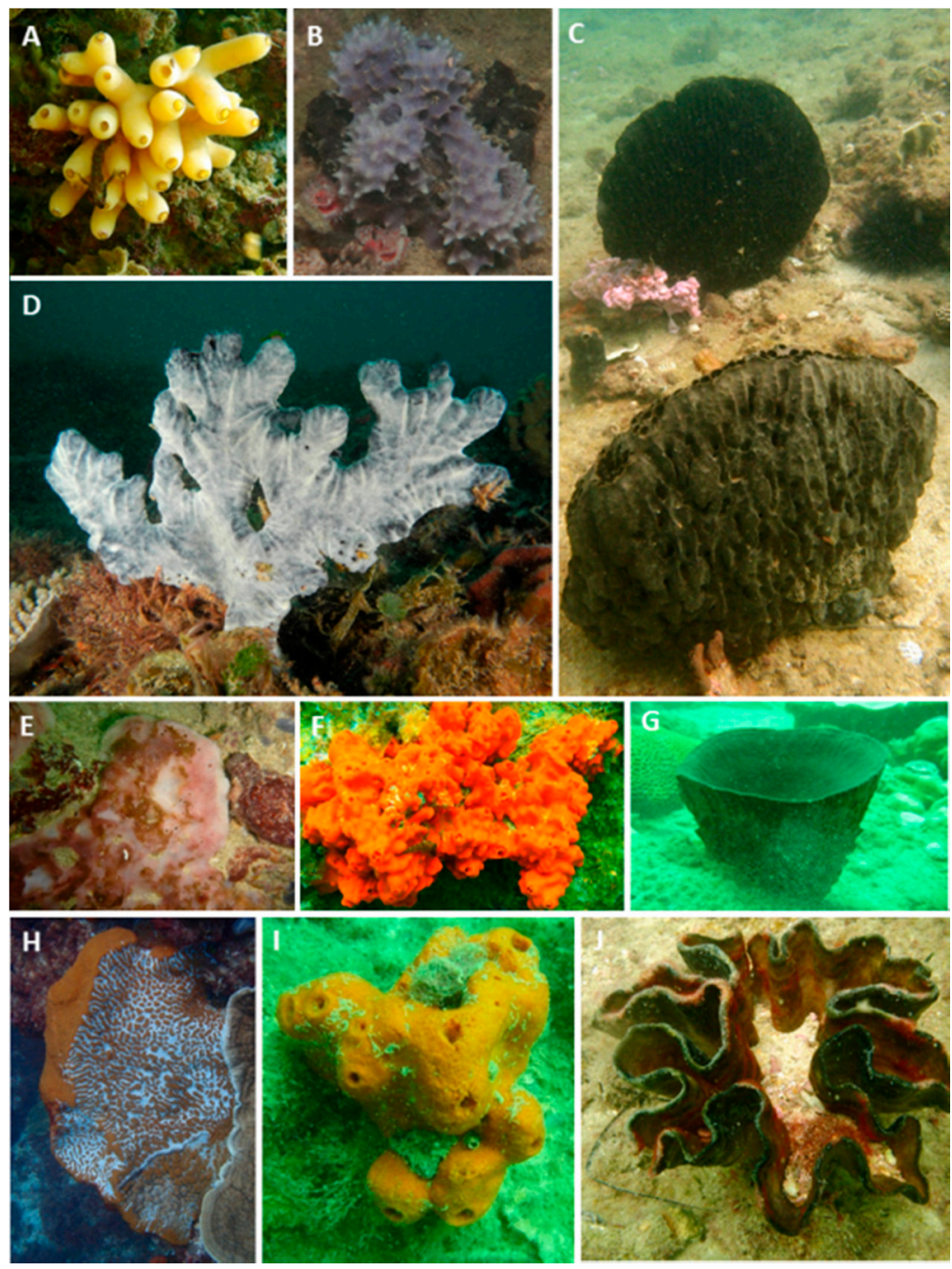

Figure 4. Sponges of Minden and Roe Reefs. (A). Sycon sp. MR1; (B). Callyspongia (Toxochalina) sp. MR1; (C). Ircinia sp. MR1; (D). Iotrochota sp. Ng1; (E). Chondrosia sp. MR1; (F). Echinochalina (Echinochalina) sp. MR1; (G). Ircinia sp. MR1; (H). Spheciospongia papillosa; (I). Microcionidae sp. MF5; (J). Echinodictyum clathrioides. 
Forty eight sponge species were identified from the two Roe Reef sites. Eleven of these were from the Class Calcarea, one from the Class Homoscleromorpha and the other 36 were Demospongiae. The most speciose order was the Poecilosclerida with 12 species recorded, followed by the Haplosclerida with six species recorded. Leucetta prolifera was the most abundant species with a total of 98 individuals counted from both sites (Figure 4). Interestingly, this species contains photosynthetic cyanobacteria and the sponge can occur in full light or shaded under a macroalgal canopy [48]. Axinella sp. L1 was also recorded in abundance (30 individuals recorded at Site 2). A further three species had 10 or more individuals, while the remaining 43 species were rare, with nine or fewer individuals counted at both sites (Table S1). A single individual of Protosuberites epiphytum was collected from Roe Reef. This species has not been recorded in WA since it was first collected in Shark Bay (described as Terpios symbioticus [49]). Furthermore, two individuals of Echinochalina cf. spongiosa were collected from Minden Reef and this species has not previously been collected in WA.

\subsection{Molluscs}

A total of 84 marine mollusc species from 46 families were collected at Minden and Roe Reefs, with 34 of these species recorded as dead molluscs (e.g., shells only). The mollusc community had a patchy distribution and composition varied within and between reefs. Only one species, the WA endemic nudibranch Chromodoris westraliensis (Figure 5H), was recorded live at all four sites. Species richness was higher at Minden Reef (48 species) than at Roe Reef (40 species). The ensuing paragraphs discuss the live molluscs observed during the two surveys unless stated otherwise.

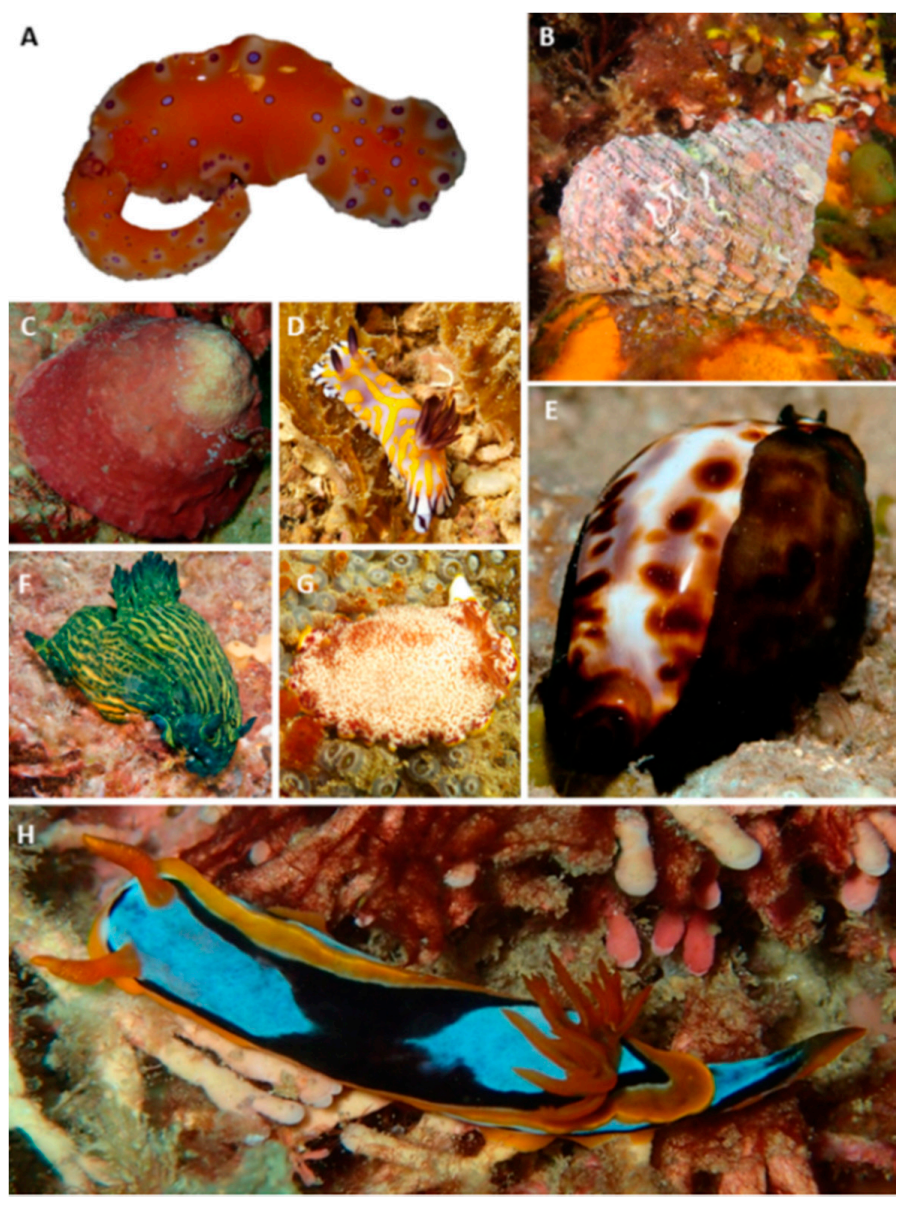

Figure 5. Molluscs of Minden and Roe Reef. (A). Cerastoma brevicaudatum; (B). Turbo kenwilliamsi; (C). Bellastraea squamifera; (D). Goniobranchus roboi; (E). Zoila friendii; (F). Tambja sp. 2; (G). Goniobranchus tinctoria and (H). Chromodoris westraliensis. 
The molluscan assemblage at Minden Reef was dominated by the attached, filter feeding community. Only nine species were recorded at both survey sites at Minden Reef (Table S1). While this indicates rather low overlap, four of these species were relatively abundant at one or both sites and thus ecologically dominant. The most abundant species recorded was the vermetid or worm snail-Thylacodes sipho (128 individuals total: 84 at Site 1, 44 at Site 2). Cleidothaerus albidus, a monotypic bivalve endemic to south-east Australia and New Zealand, was also common (59 individuals total: 24 at Site 1, 35 at Site 2), as was the tropical clasping oyster, Dendostrea folium (23 individuals at Site 2) and the hammer oyster, Malleus meridianus (23 individuals total: 16 at Site 1, seven at Site 2). The sponge living pteriomorph, Crenatula picta (14 individuals total) was also notable, as were the boring bivalves Botula tatei and Lithophaga sp. The other species observed were encountered infrequently but included several conspicuous taxa such as the vetigastropod Angaria tyria, the nudibranch Goniobranchus tinctorius (Figure 5G) and the largest gastropod in the world, Syrinx aruanus. Two Australian temperate endemic cowrie species, Zoila friendii (Figure 5E) and Z. venusta were also observed. Several pecten valves were collected ( 8 dead collected valves, WAM S82721) that were positively identified as the eastern Australian scallop Scaeochlamys livida, which is a now well-established introduced species in WA [50].

The Roe Reef molluscan fauna was more typical of southern subtidal rocky reefs and less dominated by the filter feeding community than at Minden Reef. In similarity with Minden Reef, the Roe Reef mollusc community exhibited low faunal overlap between sites (only four species were recorded at both survey sites) (Table S1), however in contrast to trends at Minden Reef, all species recorded were relatively uncommon (no more than six individuals). The large marine gastropod, Lunella torquatus was recorded at Site 2, as was Turbo kenwilliamsi (Figure 5B); both of these species were not recorded from Minden Reef. The boring bivalve Lithophaga teres was observed at Roe Reef, as were a number of nudibranchs or sea slugs (Figure 5), including Ceratosoma brevicaudatum, a southern Australian endemic (Figure 5A). The presence of the bivalve Chama pacifica was unexpected as this tropical IWP species has not been recorded in the area before. A query of the WA Museum database indicates that this record represents a $2000 \mathrm{~km}$ southward range extension (previously recorded from Broome) south. The eastern Australian scallop, Scaeochlamys livida, was also present at Roe Reef (Site 2 only, four dead collected valves, WAM S66562).

\subsection{Crustaceans}

A combined total of 70 crustacean species from five orders and 26 families were collected from Minden and Roe Reefs (Table S1), 10\% of which represent southward range extensions. While 34 species were collected from Minden Reef and 46 from Roe Reef, crustacean records were very patchy in distribution due to their cryptic and mainly nocturnal habits. Only 10 species were collected at both reefs with one species, Ancylocheles gravelei, recorded at all four sites. As expected, the Decapoda (crabs and shrimps) were the most speciose group with 46 species collected. Barnacles were the next most speciose group with 12 species, of which 11 are commensal species found inhabiting sponges and corals, and two are new species.

At Minden Reef, the Decapoda were the most speciose group with 24 species represented. In addition to $A$. gravelei, abundant species included Synalpheus neptunus (16 individuals recorded) and Pilumnus sp. 1 (12 individuals recorded) (Table S1). The barnacle species Balanus trigonus was also commonly encountered along with the isopod Oxinasphaera tuberculosa (Figure 6H). Species composition between the two sites differed greatly, with only seven species shared between Site 1 (17 species) and Site 2 (24 species). However, overall abundance of crustaceans collected was similar between sites (75 and 82 specimens respectively). Fifteen of the identified species were singletons. One of these, Zalasius dromiaeformis, has not previously been recorded in WA. The Minden Reef crustacean community was dominated by tropical species with 16 found throughout the tropical and subtropical Indo-West Pacific. The waters off the Perth metropolitan area are the southernmost limit for nine recorded species. 

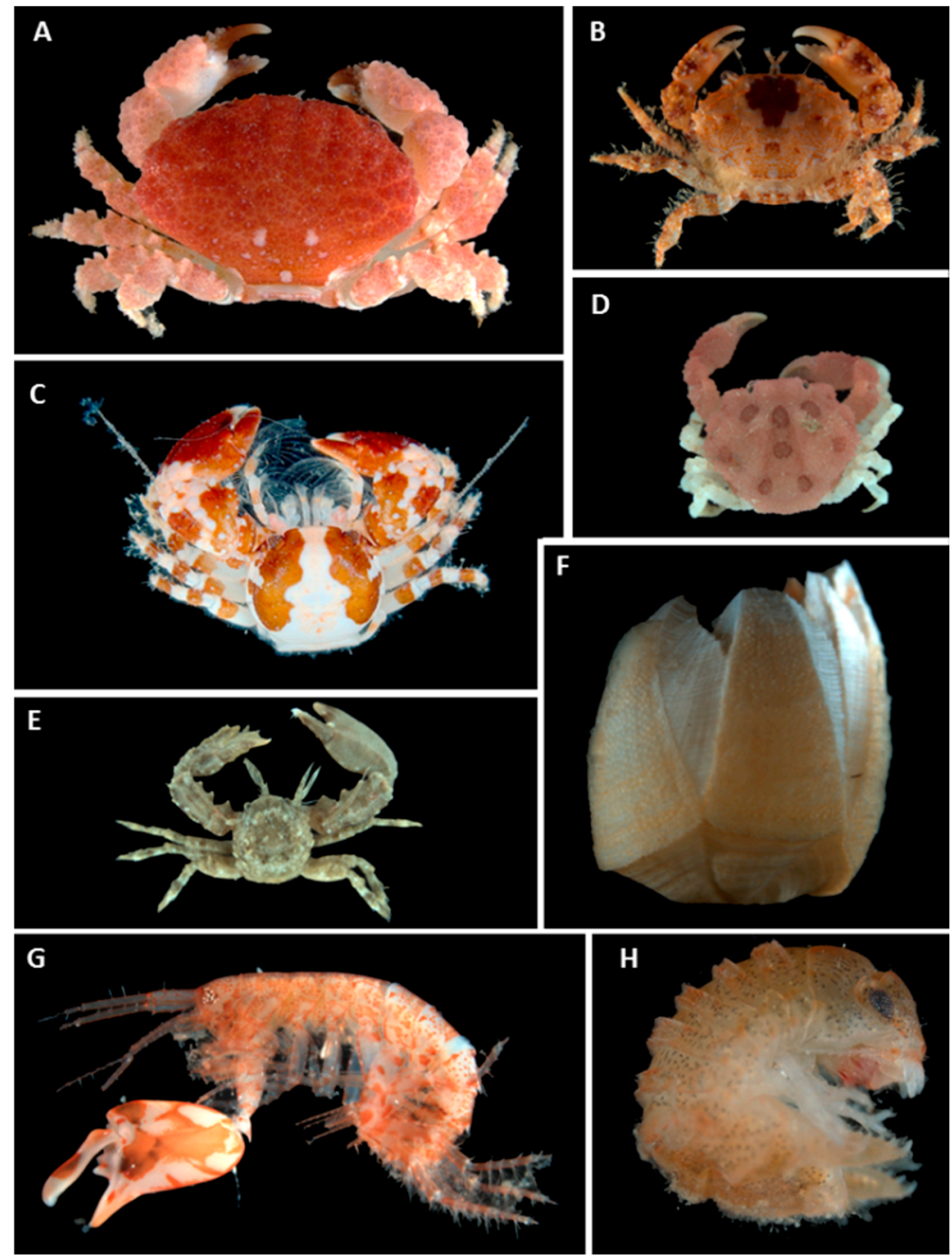

Figure 6. Crustaceans of Minden and Roe Reefs: (A). Actaea sp. 1; (B). Xanthias sp. 1; (C). Pachycheles sculptus; (D). cf. Ebalia sp. 1; (E). Pisidia dispar; (F). Euacasta sp. 1; (G). Dulichiella sp. 1; (H). Oxinasphaera tuberculosa.

At Roe Reef, the Decapoda were the most speciose group with 29 species identified, including the WA endemic species Palapedia pelsartensis and Calcinus dapsiles. However, overall abundance of crustaceans collected was slightly higher at Site 1 (77 individuals) compared to Site 2 (63 individuals). An unidentified species of melitid amphipod (sp. 1) was common at both Roe Reef sites and 10 species of barnacles were recorded (Table S1). Pilumnus rufopunctatus was also commonly encountered at both sites (21 individuals) and 11 individuals of the barnacle Armatoblanus allium were recorded. None of these three species were recorded at Minden Reef. Twenty species were represented by only a single individual (e.g., Dardanus crassimanus, Liomera margaritata and Cyclax spinicinctus). Of the barnacles recorded Armatoblanus allium has not previously been recorded south of the Houtman Abrolhos Islands and Acasta fenestrata has not previously been recorded south of the Dampier Archipelago.

\subsection{Echinoderms}

Echinoderms were collected haphazardly (excluding Site 2 at Roe Reef where no echinoderm collections were made) and their abundance was not recorded, hence the species abundances listed in Table S1 refer to presence records. Overall 30 species of echinoderms from four classes and 15 families were collected. The only species collected from both Minden and Roe Reefs was Macrophiotrix spongicola. 
Sixteen species were collected from Site 1 at Roe Reef as opposed to 14 species at Site 1 at Minden Reef, and only four species at Site 2 at Minden Reef. Numerous widespread and common species such as Echinaster varicolor (Figure 7D), Euretaster insignis (Figure 7E) and Ophiactis savignyi were present at Minden Reef, along with several species endemic to southern Australia, including Fromia polypora (Figure 7B), Clarkcoma canaliculata and Ophionereis schayeri. The south-western Australian endemic brittle star, Macrophiothrix michaelseni was collected from Minden Reef along with the brittle star, Amphiura (Amphiura) brachyactis, which has not previously been recorded south of Roebuck Bay in the Kimberley. Numerous unidentified species of brittle stars were collected from Roe Reef, and require further taxonomic investigation.
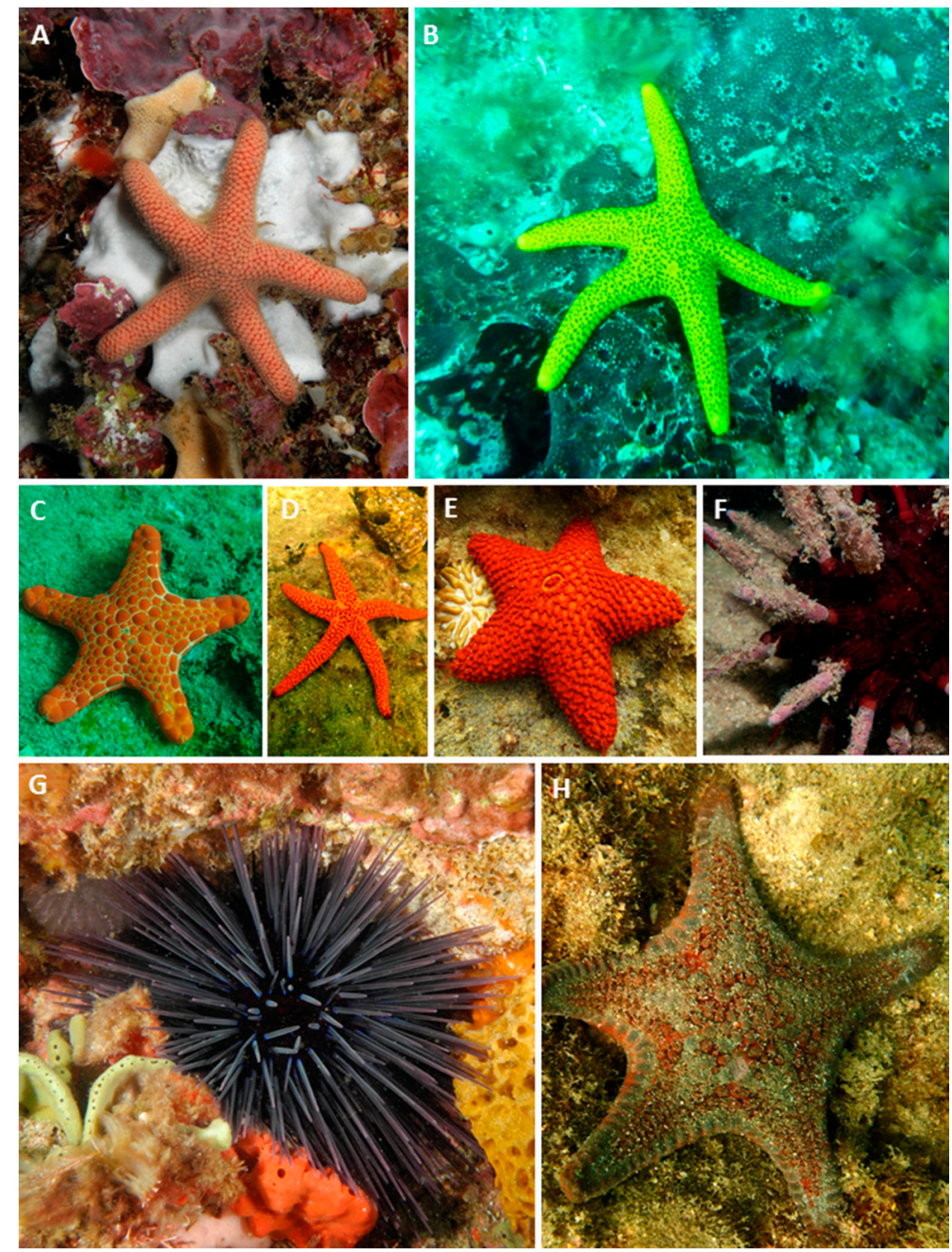

Figure 7. Echinoderms of Minden and Roe Reefs. (A). Pseudonepanthia troughtoni; (B). Fromia polypore; (C). Pentagonaster duebeni; (D). Echinaster varicolor; (E). Euretaster insignis; (F). Phyllacanthus irregularis;

(G). Centrostephanus tenuispinus; (H). Goniodiscaster seriatus.

\subsection{Fishes}

A combined total of 81 fish species were recorded across the two reefs. Forty six species were recorded from Minden Reef and 56 species from Roe Reef (Table S1). The fish fauna was a mix of temperate and tropical species, which is characteristic of Rottnest Island (Figure 8). Twenty of the 81 species (25\%) recorded are endemic to south-west WA. Twelve species were recorded at all four survey sites, including Pempheris klunzingeri (Rough Bullseye), Coris auricularis (Western King Wrasse) 
(Figure 8I) and Trachinops noarlungae (Yellowhead Hulafish), with the latter species being almost fifty times more abundant at Roe Reef than Minden Reef.
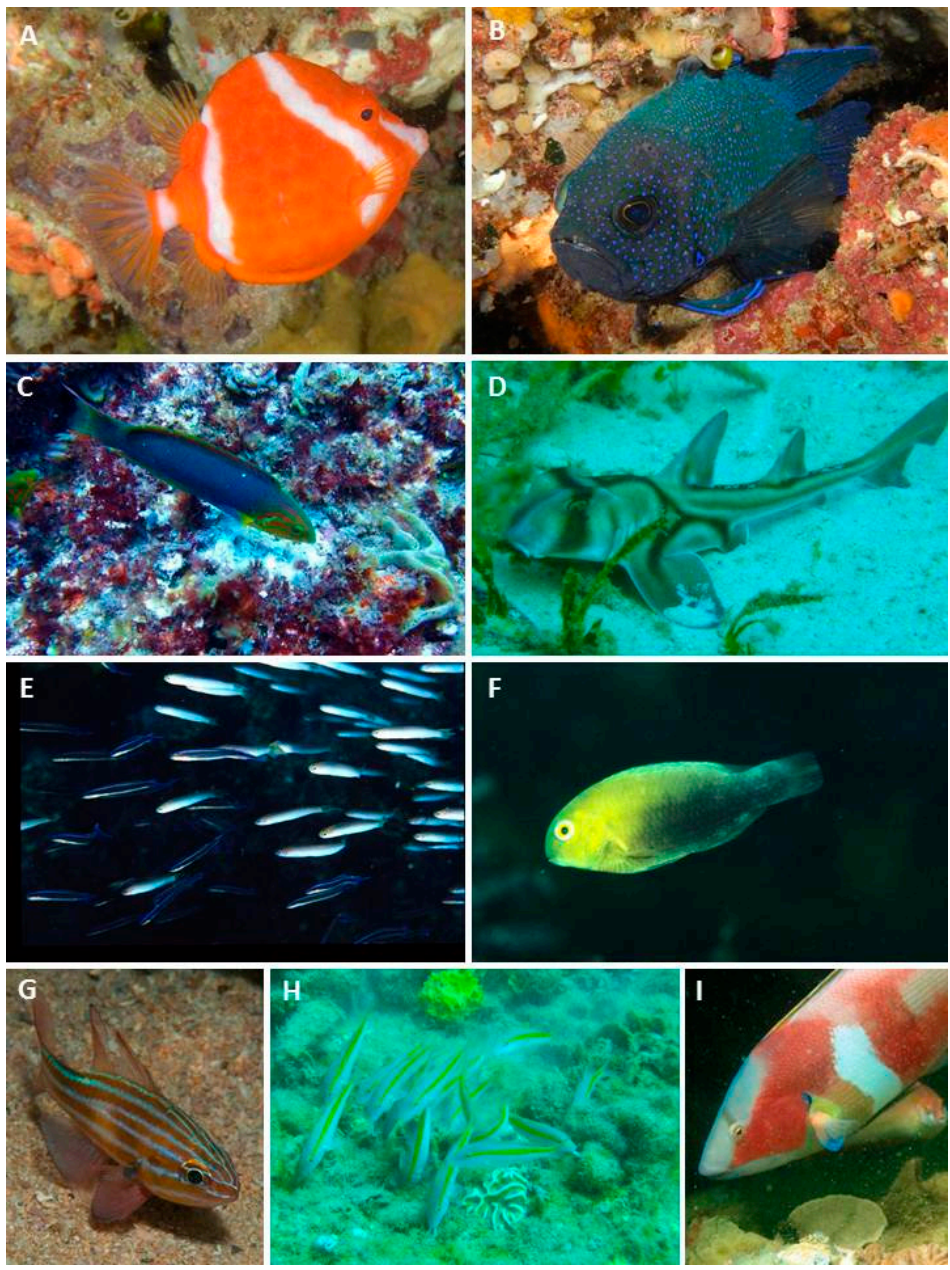

Figure 8. Fishes of Minden and Roe Reefs. (A). Anoplocapros lenticularis; (B). Common Rottnest species, Paraplesiops meleagris; (C). Uncommon tropical visitor, Thalassoma lutescens; (D). Heterodontus portusjacksoni; (E). Abundant Rottnest species, Trachinops noarlungi (yellow) and Trachinops brauni (blue, WA endemic); (F). Juvenile Choerodon rubescens, common Minden species (iconic WA endemic); (G). WA endemic, Ostorhinchus victoriae; (H). Tropical visitor, Parupeneus chrysopleuron; (I). Abundant WA endemic, Coris auricularis.

There were notable differences in the composition of fish communities between the two reefs. For example, over 700 individuals of Trachinops brauni (Bluelined Hulafish) (Figure 8E), a species endemic to south-west WA, were observed at Roe Reef but this species was not recorded at Minden Reef. Many other species, including Pemperis multiradiata (Bigscale Bullseye), Siphamia cephalotes (Wood's Siphonfish) and the iconic Glaucosoma hebraicum (Western Australian Dhufish) were only recorded at Roe Reef. Furthermore, $~ 50$ individuals of Kyphosus gladius (Gladius Chub), a species recently described from Western Australia [51], were recorded among the complex reef structure at Roe Reef.

Two apogonid species, Ostorhinchus rueppellii (Western Gobbleguts) and O. victoriae (Western Striped Cardinalfish), and the damsel, Parma occidentalis (Western Scalyfin) were observed in abundance at Minden Reef, but not recorded at Roe Reef, although all are known from Rottnest Island albeit in lower abundance. A school of the highly itinerant Seriola dumerili (Amberjack) was recorded from Minden Reef, but the species was not present at Roe Reef during the survey. Of particular note was the abundance of juveniles of the south-west WA endemic Choerodon rubescens (Baldchin Groper) at 
Minden Reef. Two Heterodontus portusjacksoni (Port Jackson Sharks) were observed at Minden Reef (Figure 8D), which is typical habitat for this species.

Nine species were only observed once, including Anoplocapros lenticularis (Whitebarred Boxfish) (Figure 8A), Latropiscis purpurissatus (Sergeant Baker), Othos dentex (Harlequin Fish) and Chaetodon assarius (Western Butterflyfish). The majority of these rarer species were observed only at Roe Reef, but Monacanthus chinensis (Fanbellied Leatherjacket) was only observed at Minden Reef.

The southernmost limit for the typical distribution of about ten species of recorded fish species is Perth (usually Rottnest). For example, an adult Pterois volitans (Common Lionfish) was observed at Roe Reef and this is one of several tropical fish species becoming more abundant at Rottnest Island. Other tropical species included Thalassoma spp ("Moon" Wrasses), Anampses geographicus (Scribbled Wrasse), Siganus fuscescens (Black Rabbitfish), and Labroides dimidatus (Common Cleanerfish).

\subsection{Marine Plants}

Marine plants were collected only at the Roe Reef sites, where 69 species were recorded, comprising 10 Chlorophyta (green algae), 18 Phaeophyceae (brown algae), 39 Rhodophyta (red algae) and two seagrasses (see Table S1). Both sites had similar species diversity and the records are combined. Some seemingly uncommon species were collected only at a single site (e.g., the red alga Platysiphonia hypneoides at Site 2), but this is most likely a collection artefact and not a reflection of the site characteristics. Several species were common at both sites, including the dominant kelp, Ecklonia radiata, various fucalean brown algae such as Scytothalia dorycarpa, and the red alga Betaphycus speciosum. Most species were previously recorded from Rottnest Island [41,52].

There was seemingly little evidence of tropicalisation based on the marine plant species present. None could be classed as representing recent southward range extensions of tropical taxa. There were also no indications that temperate species were being adversely affected; the habitat forming kelp Ecklonia radiata was abundant and in good condition, as were several other large brown algae, including Platythalia quercifolia and Scytothalia dorycarpa. Populations of the latter at Jurien Bay (220 km north of Perth, at $\sim 30.3^{\circ}$ S) were adversely affected during the 2011 "marine heat wave" [53], and the species might therefore be an indicator of climate change. The same study recorded no noticeable impact on the species at Rottnest Island, and many healthy plants were observed during the current survey.

Roe Reef is the type locality of a species of red algae, Liagora izziae (Figure 9I) described by Huisman [54] based on specimens collected in 1990. This species has not been collected since the original specimens, which were preserved in formalin solution and were therefore unsuitable for DNA analyses. The species was collected during the present survey and forms part of a large collaborative project assessing several families of red algae, including the Liagoraceae [55]. The genetic analyses will enable characterisation of this species and barcoding of Liagora izziae based on type locality material.

Material identified as Tricleocarpa cylindrica (a species originally thought to be widespread in warmer seas [56]) from the Roe Reef collections was found to be a new species in Tricleocarpa following DNA analysis. This species will be described in a future publication. Voucher specimens have been lodged with the Western Australian Herbarium, but accession numbers are not yet available.

\section{Discussion}

Here we report the presence of 427 species of marine flora and fauna from eight higher taxon groups occurring in the Perth metropolitan area. Three of these species appear to be new to science and many more may be revealed with further investigation because over 110 specimens collected in this survey require further taxonomic and molecular investigation to confirm their identity (sponges, soft corals, molluscs and crustaceans). We record for the first time 15 species that have not previously been recorded from this latitude in Western Australia and the presence of 24 species that are endemic to south-west Australia (Table 2). 

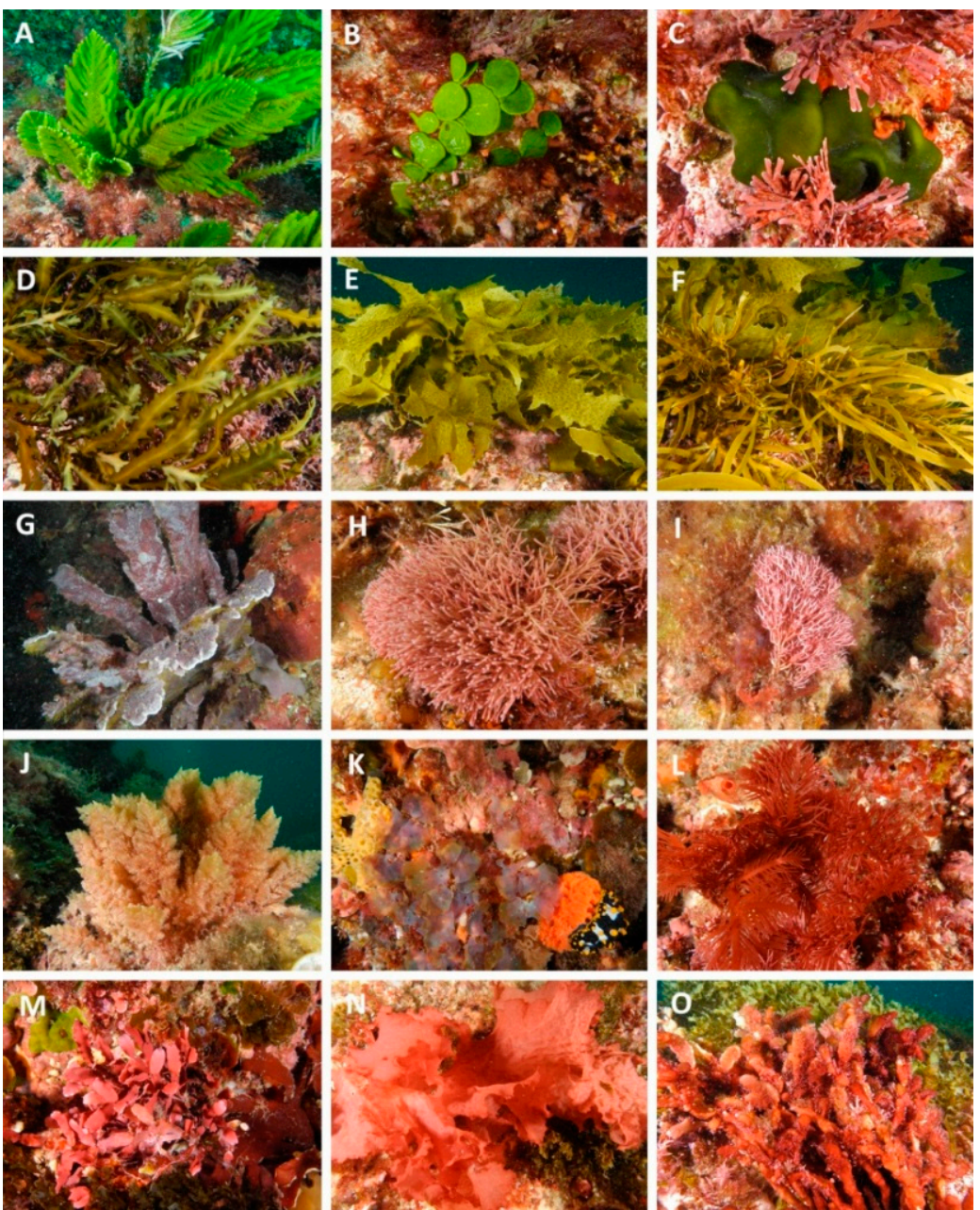

Figure 9. Marine plants of Roe Reef. (A). Caulerpa flexilis; (B). Halimeda cuneata; (C). Codium lucasii; (D). Platythalia quercifolia; (E). Ecklonia radiata; (F). Scytothalia dorycarpa; (G). Codiophyllum flabelliforme (a sponge-associated red alga); (H). Tricleocarpa, possible new species; (I). Liagora izziae; (J). Asparagopsis taxiformis; (K). Martensia sp.; (L). Callophycus sp.; (M). Rhodopeltis australis; (N). Cryptonemia kallymenioides; (O). Betaphycus speciosus.

Table 2. Putative new species, range extensions and endemic south-west Australian fauna and flora recorded in this survey. For further details about species authorities, distributions and occurrence in this survey see Table S1.

\begin{tabular}{|c|c|c|c|c|}
\hline Phylum & Species & $\begin{array}{c}\text { Putative New } \\
\text { Species }\end{array}$ & $\begin{array}{c}\text { Range } \\
\text { Extension }\end{array}$ & $\begin{array}{l}\text { Endemic to } \\
\text { South-Western } \\
\text { Australia } \\
\end{array}$ \\
\hline Arthropoda & Acasta sp. nov. & - & & \\
\hline Arthropoda & Acasta fenestrata & & - & \\
\hline Arthropoda & Armatobalanus allium & & - & \\
\hline Arthropoda & Cyclax spinicinctus & & - & \\
\hline Arthropoda & Liomera margaritata & & - & \\
\hline Arthropoda & Membranobalanus sp. 1 & & - & \\
\hline Arthropoda & Pyrogoma cancellata & & - & \\
\hline Arthropoda & Pyrogospongia sp. nov. & - & & \\
\hline Arthropoda & Synalpheus bispinosus & & - & \\
\hline Arthropoda & Zalasius dromiaeformis & & - & \\
\hline Chordata & Caesioscorpis theagenes & & & - \\
\hline Chordata & Cheilodactylus gibbosus & & & - \\
\hline
\end{tabular}


Table 2. Cont.

\begin{tabular}{|c|c|c|c|c|}
\hline Phylum & Species & $\begin{array}{l}\text { Putative New } \\
\text { Species }\end{array}$ & $\begin{array}{c}\text { Range } \\
\text { Extension }\end{array}$ & $\begin{array}{l}\text { Endemic to } \\
\text { South-Western } \\
\text { Australia }\end{array}$ \\
\hline Chordata & Choerodon rubescens & & & $\bullet$ \\
\hline Chordata & Chromis klunzingeri & & & $\bullet$ \\
\hline Chordata & Cirripectes hutchinsi & & & - \\
\hline Chordata & Coris auricularis & & & - \\
\hline Chordata & Dasyatis brevicaudata & & & $\bullet$ \\
\hline Chordata & Dotolabrus alleni & & & - \\
\hline Chordata & Epinephelides armatus & & & - \\
\hline Chordata & Glaucosoma hebraicum & & & $\bullet$ \\
\hline Chordata & Halichoeres brownfieldi & & & - \\
\hline Chordata & Kyphosus cornelii & & & - \\
\hline Chordata & Kyphosus gladius & & & - \\
\hline Chordata & Ostorhinchus victoriae & & & - \\
\hline Chordata & Parma mccullochi & & & $\bullet$ \\
\hline Chordata & Parma occidentalis & & & - \\
\hline Chordata & Pseudolabrus biserialis & & & - \\
\hline Chordata & Suezichthys cyanoleamus & & & $\bullet$ \\
\hline Chordata & Trachinops brauni & & & - \\
\hline Chordata & Trygonoptera ovalis & & & - \\
\hline Cnidaria & Alertigorgia mjoebergi & & - & \\
\hline Cnidaria & Capnella gaboensis & & - & \\
\hline Cnidaria & Favites rotundata & & $\bullet$ & \\
\hline Echinodermata & Amphiura brachyactis & & - & \\
\hline Echinodermata & Macrophiothrix michaelseni & & & $\bullet$ \\
\hline Mollusca & Chama pacifica & & $\bullet$ & \\
\hline Porifera & Cymbastela marshae & & & - \\
\hline Porifera & Echinochalina spongiosa & & $\bullet$ & \\
\hline Porifera & Haliclona sp. & & & - \\
\hline Porifera & Leucetta prolifera & & & - \\
\hline Porifera & Protosuberites epiphytum & & - & \\
\hline \multirow[t]{2}{*}{ Plantae } & Tricleocarpa new sp. & - & & \\
\hline & TOTAL & 3 & 15 & 24 \\
\hline
\end{tabular}

Although the flora and fauna of Roe Reef has not been the subject of quantitative scientific investigation it is a popular recreational dive site and the fish, algae and crustacean communities have been examined on various occasions [42,43]. However, Minden Reef is a little known location that is rarely visited by recreational divers and to our knowledge has never been the focus of a formal marine survey. The results of these surveys add to our knowledge of local nearshore marine environments and support a growing body of evidence of a diverse and regionally significant marine fauna in temperate WA.

The overall diversity of fauna was slightly higher at Roe Reef (218 species vs. 187 species), although a similar number of species was recorded at sites within reefs. Slight differences in survey effort and survey depths prevent statistical comparisons within and between sites. Nevertheless, it was clear from our surveys that the two reefs, despite being only $21 \mathrm{~km}$ apart, contained very different communities. For example, the biomass of hard corals at Minden Reef is approximately three times higher than recorded at Roe Reef and the biomass of soft corals is two times higher at Minden Reef. The temperate water specialist Coscinarea marshae, was only observed at Roe Reef, and Pocillopora damicornis and Montipora mollis were not encountered at Minden Reef, even though these coral species were abundant at Roe Reef. Other than Chromodoris westraliensis, the charismatic sea slug or nudibranch fauna was either a "Minden" fauna or a "Roe" fauna (Table S1). Further, Trachinops brauni (Bluelined Hulafish), which is endemic to south-west WA was observed in abundance at Roe Reef, but not recorded at Minden Reef. Similarly, Trachinops noarlungae (Yellowhead Hulafish) was almost fifty times more abundant at Roe Reef than Minden Reef. It also appears that Minden Reef may be a nursery for juvenile Choerodon rubescens, the heavily fished Baldchin Groper.

The spatial heterogeneity of community composition is further reinforced by the finding that no species of hard coral, soft coral or sponge were recorded at all survey sites. One 
mollusc (Chromodoris westraliensis), one echinoderm (Centrostephanus tenuispinus), one decapod (Ancylocheles gravelei) and 12 species of fishes were the only organisms recorded at all sites (Table S1). The spatial differences in community composition relate, in part, to the different topographic and environmental settings of the reefs. For example, Minden Reef lies just $2 \mathrm{~km}$ offshore whereas Roe Reef is $20 \mathrm{~km}$ offshore and $1.6 \mathrm{~km}$ from Rottnest Island. Minden Reef is a small, low profile reef compared to Roe Reef's topographical complexity incorporating caves and vertical reef faces. Minden Reef's inshore location, protected by more seaward reefs between Garden and Rottnest Islands, combined with its close proximity to Fremantle Harbour, has resulted in a high sediment regime. As a result marine communities are dominated by abiotic material (sand, silt, rock and maritime wreckage, see Figure 2J), and on the southern side of the reef, by seagrass. In contrast, Roe Reef generally experiences comparatively clear water conditions with a higher energy regime and is dominated by a variety of flora, including turf algae, brown algae and kelp.

Amongst our results are numerous important findings, particularly the discovery of undescribed species on the doorstep of another one of Australia's major capital cities [57]. Firstly, a new species of red algae has been determined from fresh tissue collected at Roe Reef. Secondly, two new species of sponge barnacle were collected, one each from Minden and Roe Reefs. One of these provides the first record of the genus Pyrgospongia in Australia. Our data also extends the known range of 15 species and in numerous instances, thousands of kilometres southwards. For example, the xanthid crab, Zalasius dromiaeformis from Minden Reef has not previously been recorded from Western Australia. The barnacle Acasta fenestrata collected from both Minden and Roe Reefs, and the shrimp Synalpheus bispinosus, collected from Minden Reef, have not previously been recorded south of the Dampier Archipelago. Similarly, a species of brittle star, Amphiura (Amphiura) brachyactis, collected from Minden Reef, has not previously been recorded south of Roebuck Bay, Kimberley. The cemented clam Chama pacifica collected at Roe Reef has not previously been recorded south of Broome. The distribution of Alertigorgia mjöbergi, a tropical octocoral species previously known as far south as Exmouth, has been confirmed at Minden Reef. This study also provides the first record of the sponge Protosuberites epiphytum, collected from Roe Reef, occurring south of Shark Bay. Numerous other species had their known range extended south from the Houtman Abrolhos Islands (e.g., Favites rotundata, Cyclax spinicinctus, Liomera margaritata, Armatobalanaus allium, Pyrgoma cancellata) as a result of this survey. These latter two species are only the second and third species of coral inhabiting barnacles to be reported in the Perth area, as well as representing some of the most southerly records for this group. The only other coral barnacle species from the region is Pyrgomina djanae, a southern WA endemic [58].

Few studies have examined the sponge fauna of the temperate regions of Western Australia. The sponges of Minden Reef were reported in a newspaper article in 1907 [59], which mentioned the high incidence of sponges found at Minden Reef (and surrounding temperate locations) in the context of development of a bath sponge industry. At that time the most commonly used species for this industry were those belonging to the genera Spongia and Hippospongia. Species of both of these genera were reported in our survey, but they were not common-one and five individuals respectively. Based on previous studies $[60,61]$ it can be determined that of the 67 sponge species reported here, 11 are known to occur in local habitats, two are new records and the remaining 54 species require additional taxonomic comparisons.

It is important to note that only one introduced species was recorded in these surveys, the east Australian scallop Scaeochlamys livida [50]. This species is now established in Western Australia and was recorded at both reefs (based on dead valves). While increased incidence and movement of certain pest species with climate change is expected globally this is subject of ongoing study [62] and requires further attention in the Perth transition zone.

Cypraeidae or cowries are a widespread, attractive and diverse family of gastropod molluscs, many of which are targeted by collectors. In Western Australia, an active group of professional collectors has been monitoring distribution and abundance of several target taxa, including the highly sought after Australian endemic genus Zoila, for many years. Because of this longstanding interest, 
cowries represent a viable model system to track range shifts and new arrivals through citizen science partnerships, much like coordinated nudibranch surveys have recently galvanized community efforts to monitor faunal change on the east coast [10]. The survey at Minden Reef documented both of the two species known to occur there, the direct developing Zoila friendii friendii and Z. venusta. These two species have been observed in the area for at least the previous 25 years. To date there are no records of any settlement by free drifting veligers of other Cypraea species at Minden Reef. No cowries were observed during the survey of Roe Reef. This in contrast to historical data that indicate quite a diverse cowrie fauna of approximately 22 species exists at Rottnest Island (of which Roe Reef is a part). Of these, ten have been confirmed to represent breeding populations (e.g., egg masses observed) and almost all represent temperate species and/or temperate endemics (see Table S2). In contrast, the other twelve species are considered to be recent arrivals and possibly tropical vagrants; all twelve are well-known tropical (IWP) species. Most of these are known only from dead collected shells indicating that these records are unlikely to represent established populations, however several species have been found live, including the soft coral predator, Ovula ovum or egg cowrie (see Table S2). Although these are preliminary findings, there is a clear signature emerging of a slow, but constant influx of tropical species arriving at Rottnest Island over the past 50 years. One species that has potentially disappeared from Rottnest Island is Notocypraea pulicaria. It is a southern Australian endemic, like all members of the genus. This species was recorded from the island in the 1930s and has not been observed live at Rottnest Island since.

This data set verifies that some level of tropicalisation of reef communities in the Perth metropolitan area is occurring. The past two decades has seen strengthening of the Leeuwin Current [63], which may explain the occurrence of some of these and other more tropical species, such as Pterois volitans (Common Lionfish), Anampses geographicus (Scribbled Wrasse), Siganus fuscescens (Black Rabbitfish), and Labroides dimidatus (Common Cleanerfish) occurring adjacent to Perth [64]. Previous reports indicate the southern distributions of many species of tropical fishes are extending as a consequence of warming sea temperatures in Western Australia [65,66]. A growing body of evidence suggests that climate driven range extensions of tropical herbivores, especially fishes, can dramatically alter algal ecosystems [67]. Excessive grazing by new tropical colonists can reduce temperate reefs previously densely covered with macroalgae to a canopy-free state dominated by turf species, especially when the algae are also under warm water stress $[27,68]$. Although the strengthening of the Leeuwin Current has been well documented in recent decades, it is expected to weaken under climate change predictions into the future [63]. These counterintuitive shifts in abiotic variables will dictate similarly complex responses in biotic systems.

While some of the new records may be attributed to a lack of previous survey effort, there are many examples of significant range extensions in this dataset (Table 3). Chama pacifica can be cryptic, with a shell overgrown by epibionts, but the Perth metropolitan area has been visited extensively over several decades and this species has not previously been recorded. If the reef communities in the Perth metropolitan area are becoming tropicalised as suggested by this study, this will have ecological and perhaps evolutionary ramifications for locally endemic species. Ordinarily, the decadal cycle of Leeuwin Current weakening (with lessening propagule pressure) would result in many tropical vagrants disappearing from southern limits. However, since the predicted Leeuwin weakening will coincide with continued global seawater warming, it is likely that many vagrants will remain and establish as sustainable populations.

The species abundance and distribution records presented here are conservative. We acknowledge our surveys covered only a small area, and in some cases the high level of Ecklonia cover obscured other benthos making the documentation of some benthic fauna, such as sponges, problematic. Furthermore, it is difficult to survey molluscs and crustaceans during daylight hours as many are nocturnal and cryptic by nature. Furthermore, some fauna such as nudibranchs may be seasonal. As a result, diversity of these taxa has almost certainly been under-represented. Surveying the fish fauna at one point in time is unlikely to capture the true diversity of fishes, other than those that are site attached. Although 
the hard and soft coral records provide a reliable representation of the diversity of those taxa at Minden and Roe Reefs, additional species may be encountered with further surveys. It is interesting to note that that all but four of the scleractinian coral species recorded from a previous survey at nearby Hall Bank ( 3 km north of Minden Reef; [38]) were recorded in this survey. Two species present at Minden Reef in the present study (Goniopora pendulus, Turbinaria peltata), were not recorded at Hall Bank, despite the latter reef having a far greater benthic cover of corals ( $>67 \%)$. Taxonomic biases are not likely to explain this result as both species are distinctive and easily identified. This finding is perhaps a reflection of the heterogeneity of communities in the Perth metropolitan transition zone and substantiates the need for thorough survey effort to detect diversity.

Table 3. Specific details about the putative range extensions including possible explanations for the new records.

\begin{tabular}{|c|c|c|c|c|}
\hline Class & Species & Previous Known Range & km Range Extension & $\begin{array}{l}\text { Possible Explanation } \\
\text { for Range Extension }\end{array}$ \\
\hline Arthropoda & Acasta fenestrata & Dampier, WA & $\sim 1265 \mathrm{~km}$ & Most likely overlooked \\
\hline Arthropoda & Armatobalanus allium & Abrolhos Is., WA & $\sim 410 \mathrm{~km}$ & Most likely overlooked \\
\hline Arthropoda & Cyclax spinicinctus & Abrolhos Is., WA & $\sim 410 \mathrm{~km}$ & Most likely overlooked \\
\hline Arthropoda & Liomera margaritata & Abrolhos Is., WA & $\sim 410 \mathrm{~km}$ & Most likely overlooked \\
\hline Arthropoda & Membranobalanus sp. 1 & Arafura Sea, NT & $\sim 3380 \mathrm{~km}$ & $\begin{array}{l}\text { Genus most likely overlooked. } \\
\text { Requires further investigation to } \\
\text { confirm species }\end{array}$ \\
\hline Arthropoda & Pyrogoma cancellata & Abrolhos Is., WA & $\sim 410 \mathrm{~km}$ & $\begin{array}{l}\text { Possibly overlooked or } \\
\text { misidentified in past surveys }\end{array}$ \\
\hline Arthropoda & Synalpheus bispinosus & Dampier, WA & $\sim 1265 \mathrm{~km}$ & $\begin{array}{l}\text { Possibly overlooked or } \\
\text { misidentified in past surveys }\end{array}$ \\
\hline Arthropoda & Zalasius dromiaeformis & Gulf of Carpentaria, QLD & $\sim 3000 \mathrm{~km}$ & $\begin{array}{l}\text { Most likely genuine } \\
\text { range extension }\end{array}$ \\
\hline Cnidaria & Alertigorgia mjoebergi & $\begin{array}{l}\text { North-West Australia, } \\
\text { North of Exmouth, WA }\end{array}$ & $\sim 1300 \mathrm{~km}$ & $\begin{array}{l}\text { Most likely genuine } \\
\text { range extension }\end{array}$ \\
\hline Cnidaria & Capnella gaboensis & $\begin{array}{c}\text { Southern Queensland, } \\
\text { New South Wales, Victoria } \\
\text { to South Australia } \\
\text { (Waldegrave Island) }\end{array}$ & $\sim 2300 \mathrm{~km}$ & $\begin{array}{l}\text { Most likely overlooked but } \\
\text { possibly a genuine } \\
\text { range extension }\end{array}$ \\
\hline Cnidaria & Favites rotundata & $\begin{array}{c}\text { Indo-west Pacific, } \\
\text { including east and } \\
\text { western Australia. Most } \\
\text { southerly WA record is } \\
\text { Abrolhos Is., WA }\end{array}$ & $\sim 410 \mathrm{~km}$ & $\begin{array}{l}\text { Possibly overlooked or } \\
\text { misidentified in past surveys }\end{array}$ \\
\hline Echinodermata & Amphiura brachyactis & Roebuck Bay, WA & $\sim 1696 \mathrm{~km}$ & $\begin{array}{l}\text { Most likely genuine range } \\
\text { extension from larval dispersal }\end{array}$ \\
\hline Mollusca & Chama pacifica & $\begin{array}{l}\text { Indo-west Pacific, } \\
\text { previously known from } \\
\text { Broome, WA }\end{array}$ & $\sim 1700 \mathrm{~km}$ & $\begin{array}{l}\text { Most likely genuine range } \\
\text { extension from larval dispersal }\end{array}$ \\
\hline Porifera & Echinochalina spongiosa & $\begin{array}{l}\text { Only known from the type } \\
\text { locality-Port Phillip Bay, } \\
\text { VIC }\end{array}$ & $\sim 2740 \mathrm{~km}$ & $\begin{array}{l}\text { Most likely genuine range } \\
\text { extension with lack of sampling in } \\
\text { between localities causing } \\
\text { disjunct distribution }\end{array}$ \\
\hline Porifera & Protosuberites epiphytum & $\begin{array}{c}\text { Great Barrier Reef, Port } \\
\text { Phillip Bay VIC and Shark } \\
\text { Bay, WA }\end{array}$ & $\sim 690 \mathrm{~km}$ & $\begin{array}{l}\text { Most likely genuine range } \\
\text { extension with lack of sampling in } \\
\text { between localities causing } \\
\text { disjunct distribution }\end{array}$ \\
\hline
\end{tabular}

As marine environments and their associated faunal assemblages continually adjust to global warming trends, the accumulation of baseline biodiversity data is critical. This is particularly important along the margins of recognised transition zones on continuous coastlines, such as the temperate reefs surveyed here. Although, range shifts can be subtle and often difficult to document, other effects are clearer, with the impacts of heightened sea surface temperatures already apparent along the WA coast. Endemic corals growing on high latitude reefs have proven susceptible to thermal bleaching from anomalous warming events as was observed with Coscinaraea marshae at Rottnest Island [69] after the 2011 "marine heat wave" that affected Western Australian coral reefs across $12^{\circ}$ of latitude [70,71]. Ongoing monitoring of community composition is the only way to better understand the conservation implications of climate changes affecting local environments. The positions of these sites adjacent to a major metropolitan center should enable monitoring by the marine science community, to not 
only further document baseline biodiversity but also track the incidence of warm water invasive species. Ongoing monitoring of the composition and structure of marine communities in the Perth metropolitan transition zone is needed to quantify the extent and rate of change and to justify any future management interventions that may be initiated to protect potentially at risk endemic south-west fauna [72].

Observation in different locations and seasons is required to more accurately capture the diversity of marine life in the Perth metropolitan area. For example, many nudibranchs are temporally and/or spatially rare and may not be detected in an area for long periods (e.g., Goniobranchus aurigera, known only from the holotype collected in 1986 at Quinns Rocks). Many species known from historical records were not observed during the two surveys and whether this indicates a true absence or statistical absence due to a lack of survey effort remains to be established. Furthermore, the roving nature of pelagic and mobile fishes, the cryptic and nocturnal nature of crustaceans, and the seasonal nature of marine algae may have contributed to the level of diversity being underreported which would increase with further work.

\section{Materials and Methods}

\subsection{Site Description}

Minden Reef is $2 \mathrm{~km}$ from the Western Australian coastline and just south of the Fremantle Harbour entrance (Figure 10) in $8 \mathrm{~m}$ of water. It is a small (240 $\mathrm{m}$ long $\times 80 \mathrm{~m}$ at the widest point) isolated, low profile limestone reef with broken edges forming a perimeter-ledge varying in height from 1 to $3 \mathrm{~m}$. The reef is surrounded by extensive sandy plains and sparse seagrass meadows (Figure 11). The site is littered with maritime wreckage, including metal, bottles and coal that have accumulated over the past 180 years.

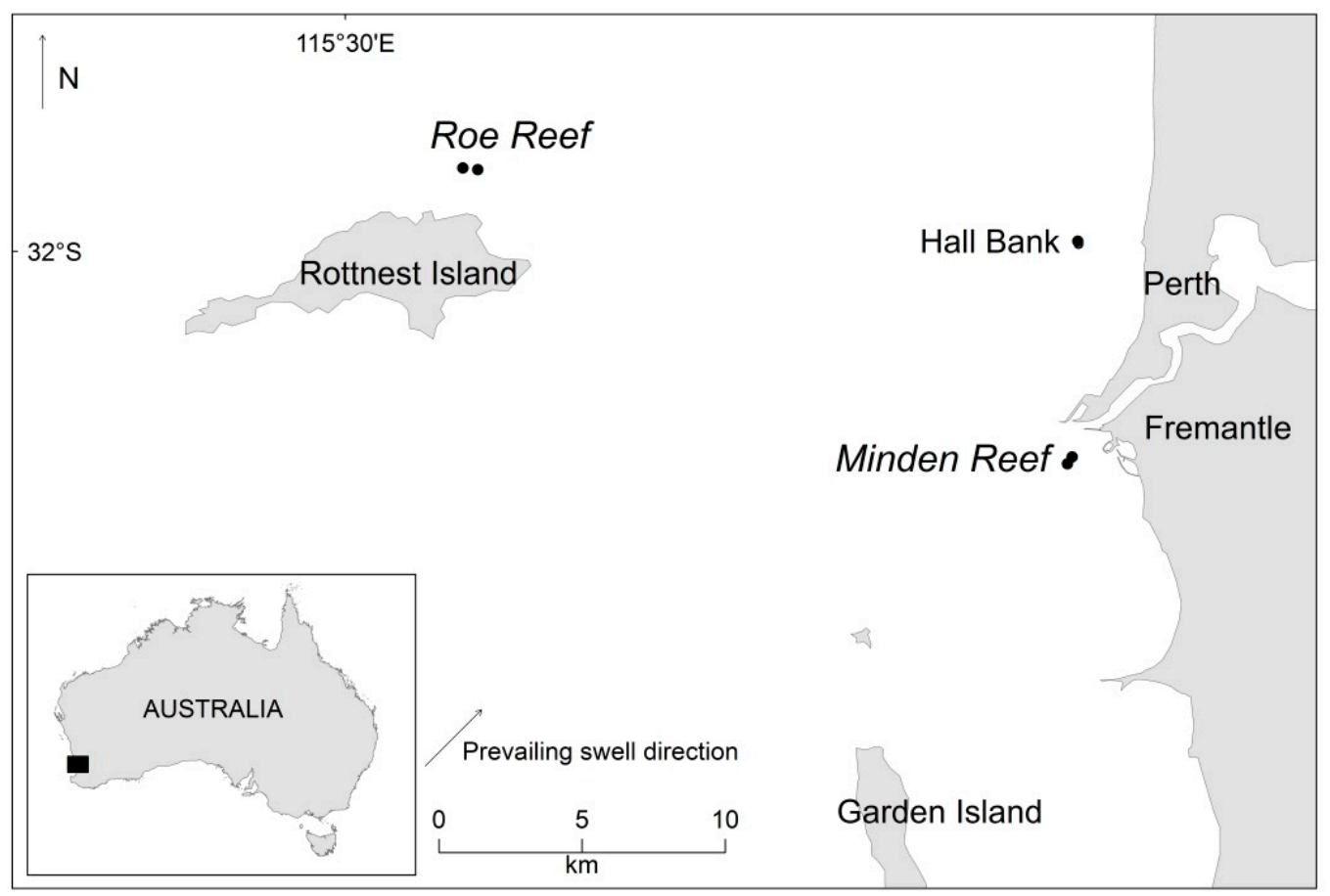

Figure 10. Map of study sites. 

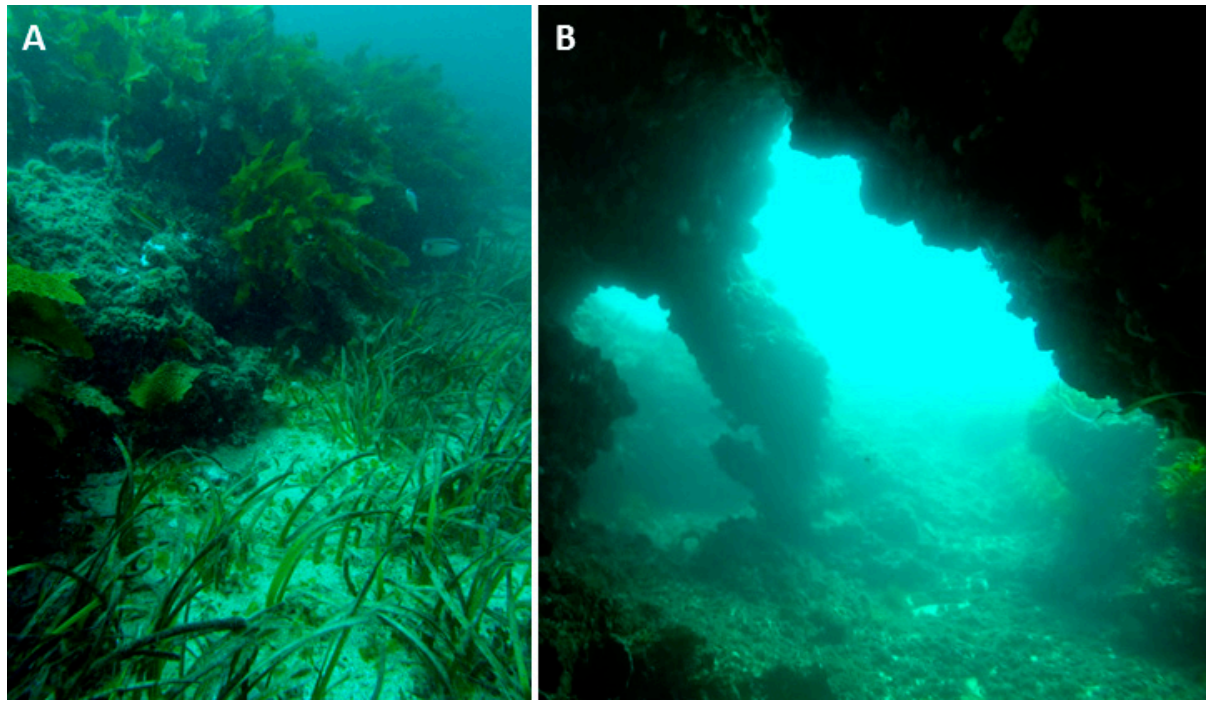

Figure 11. Topographic complexity of (A) Minden Reef; and (B) Roe Reef.

Roe Reef is situated on the north eastern side of Rottnest Island in 12-20 m of water and is within a marine protected area administered by the Rottnest Island Authority (Figure 10). It is a small, relatively flat-topped limestone reef $(1500 \mathrm{~m} \times 1000 \mathrm{~m})$ rising 2 to $6 \mathrm{~m}$ from the sea floor. The reef is protected from the prevailing south-west winds and associated wind-driven seas. However, it is subject to winter swells producing high energy wave action across the reef at these times. As a result, the reef is topographically complex with undercut, cavernous edges and caves of various sizes offering high habitat heterogeneity for associated fauna (Figure 11).

\subsection{Field Surveys}

Two sites were surveyed at each reef in early autumn of 2013 (Minden) and summer of 2014 (Roe) (See Table 4 for further site and survey details). Each site was surveyed by Underwater Visual Census (UVC) on SCUBA for one hour. Detailed quantitative assessments were conducted for most faunal groups using replicated belt transects and additional, opportunistic sampling (off transect) was also undertaken for some groups to provide overall species inventories. Fauna from eight major marine taxa were surveyed and many vouchers were collected to confirm identification and/or add to the collections of WAM. See Table 5 for taxon-specific survey and sample preservation methods.

Table 4. Description of survey sites including timing of surveys, depth and coordinates.

\begin{tabular}{ccccccc}
\hline Location & Site & Aspect & Depth & Latitude (South) & Longitude (East) & Exposure \\
\hline $\begin{array}{c}\text { Minden Reef 13th } \\
\text { March 2013 }\end{array}$ & Site 1 & North & $8-10 \mathrm{~m}$ & $32.0401^{\circ}$ & $115.4362^{\circ}$ & $\begin{array}{l}\text { Partially protected from prevailing } \\
\text { south-west winds by an } \\
\text { interconnecting reef system between } \\
\text { Garden and Rottnest Islands. It lies } \\
\text { within a sediment deposition zone. }\end{array}$ \\
\hline $\begin{array}{c}\text { Roe Reef 6th } \\
\text { February 2014 }\end{array}$ & Site 1 & South & $8-10 \mathrm{~m}$ & $32.0408^{\circ}$ & $115.4362^{\circ}$ & $\begin{array}{l}\text { Protected from prevailing south-west } \\
\text { winds and associated wind-driven } \\
\text { seas. Subject to winter swells } \\
\text { wrapping around the western end of } \\
\text { Rottnest Island, which run along the } \\
\text { northern side and over the reef. } \\
\text { Larger swells break producing } \\
\text { high-energy wave action across the } \\
\text { reef at these times. }\end{array}$ \\
\hline
\end{tabular}


Table 5. Taxon-specific survey methods.

\begin{tabular}{|c|c|c|c|}
\hline Data/Taxon & Method & Sample Preservation & $\begin{array}{l}\text { Surveyor, Collector } \\
\text { And/Or Taxonomist }\end{array}$ \\
\hline Benthic Cover & $\begin{array}{l}\text { Four } 15 \mathrm{~m} \text { point-intercept transects-every } \\
15 \mathrm{~cm} \text { under tape }=100 \text { points per transect }\end{array}$ & NA & Clay Bryce \\
\hline Hard Corals & $\begin{array}{l}\text { Four } 15 \mathrm{~m} \times 1 \mathrm{~m} \text { wide belt transects plus } \\
20 \mathrm{~min} \text { swim off-transect }\end{array}$ & $100 \%$ ethanol (wet); bleach (dry) & Zoe Richards \\
\hline Soft Corals & $\begin{array}{l}\text { Four } 15 \mathrm{~m} \times 1 \mathrm{~m} \text { wide belt transects plus } \\
20 \mathrm{~min} \text { swim off-transect }\end{array}$ & $70 \%$ ethanol & Monika Bryce \\
\hline Sponges & Four $15 \mathrm{~m} \times 1 \mathrm{~m}$ wide belt transects & $70 \%$ ethanol & Jane Fromont, Oliver Gomez \\
\hline Molluscs & $\begin{array}{l}\text { Four } 15 \mathrm{~m} \times 1 \mathrm{~m} \text { wide belt transects plus } \\
20 \mathrm{~min} \text { swim off-transect }\end{array}$ & $100 \%$ ethanol & $\begin{array}{l}\text { Lisa Kirkendale, Corey } \\
\text { Whisson, Nerida Wilson, Glad } \\
\text { Hansen, Hugh Morrison }\end{array}$ \\
\hline Crustacea & $\begin{array}{l}\text { Four } 15 \mathrm{~m} \times 1 \mathrm{~m} \text { wide belt transects plus } \\
\text { representative samples of potential habitat } \\
\text { such as sponges, seaweeds and rubble, } \\
\text { collected and sorted in the laboratory. } \\
\text { Additional ad hoc off-transect collections }\end{array}$ & $100 \%$ ethanol & $\begin{array}{l}\text { Andrew Hosie, Ana Hara, } \\
\text { Lee Betterridge }\end{array}$ \\
\hline Echinoderms & $\begin{array}{l}\text { Incidental collections (Minden Reef } \\
\text { and Roe Reef Site } 1 \text { only) }\end{array}$ & $100 \%$ ethanol & $\begin{array}{l}\text { Courtney Wood, Jenelle Ritchie, } \\
\text { Loisette Marsh }\end{array}$ \\
\hline Fishes & Six $50 \mathrm{~m} \times 5 \mathrm{~m}$ wide belt transects & UVC or photographed & Glenn Moore, Sue Morrison \\
\hline Flora & $\begin{array}{l}\text { One hour rapid visual assessment } \\
\text { (Roe Reef only) }\end{array}$ & Pressed; dried in silica gel & John Huisman \\
\hline
\end{tabular}

\section{Conclusions}

Reefs in the vicinity of the Perth metropolitan area support regionally significant flora and fauna. Minden and Roe Reefs occur in a known tropical-temperate transition zone, and require further survey effort to be well characterised. Climate mediated changes in species distribution patterns have the potential to profoundly alter temperate marine communities and the results of this study confirm tropicalisation is occurring in the vicinity of Perth. These community changes may have deleterious consequences for species that are endemic to south-west WA hence the future of WA's temperate marine biodiversity must be closely monitored and managed. Traditional survey work and citizen science approaches could both contribute to this effort.

Supplementary Materials: The following are available online at www.mdpi.com/1424-2818/8/2/7/s1, Table S1: Annotated Checklist of the Marine Fauna and Flora collected (or photographed) at Minden and Roe Reefs. Table S2. Cowrie fauna of Rottnest Island.

Acknowledgments: Funding for this work from the Butler Bequest, administered by the WA Museum Foundation, is hereby acknowledged. The Rottnest Island Authority provided the permit to undertake research at Roe Reef, and DPaW permits were approved for both reef projects.

Author Contributions: Jane Fromont, Zoe Richards, Lisa Kirkendale, Glenn Moore conceived the study; Zoe Richards, Lisa Kirkendale, Glenn Moore wrote the paper; Zoe Richards, Lisa Kirkendale, Glenn Moore, Andrew Hosie, John Huisman, Monika Bryce, Clay Bryce, Susan Morrison, Ana Hara, Oliver Gomez, Nerida Wilson, Jenelle Ritchie, Lee Betterridge, Courtney Wood. collected the data; Zoe Richards, Lisa Kirkendale, Glenn Moore, Jane Fromont, Andrew Hosie, John Huisman, Monika Bryce, Loisette Marsh analyzed the data; Nerida Wilson, A.Ho., Jane Fromont, Mark Allen, Clay Bryce, Monika Bryce, Corey Whisson edited the paper; Ana Hara created the map; Nerida Wilson, Hugh Morrison, Glad Hansen, Shirley Slack-Smith provided taxonomic expertise;. Ana Hara, Susan Morrison, Oliver Gomez, Mark Allen, Corey Whisson, Jenelle Ritchie, Lee Betterridge, Mark Salotti provided technical or curatorial assistance.

Conflicts of Interest: The authors declare no conflict of interest. The founding sponsors had no role in the design of the study; in the collection, analyses, or interpretation of data; in the writing of the manuscript, and in the decision to publish the results.

\section{References}

1. Rosenzweig, C.; Neofotis, P. Detection and attribution of anthropogenic climate change impacts. WIREs Clim. Change 2013, 4, 121-150. [CrossRef]

2. Precht, W.F.; Aronson, R.B. Climate flickers and range shifts of reef corals. Front. Ecol. Environ. 2004, 2, 307-314. [CrossRef] 
3. Ling, S.D.; Johnson, C.R.; Ridgway, K.; Hobday, A.J.; Haddon, M. Climate-driven range extension of a sea urchin: Inferring future trends by analysis of recent population dynamics. Glob. Change Biol. 2009, 15, 719-731. [CrossRef]

4. Last, P.R.; White, W.T.; Gledhill, D.C.; Hobday, A.J.; Brown, R.; Edgar, G.J.; Pecl, G. Long-term shifts in abundance and distribution of a temperate fish fauna: A response to climate change and fishing practices. Glob. Ecol. Biogeogr. 2011, 20, 58-72. [CrossRef]

5. Pitt, N.R.; Poloczanska, E.S.; Hobday, A.J. Climate-driven range changes in Tasmanian intertidal fauna. Mar. Freshw. Res. 2010, 61, 963-970. [CrossRef]

6. Yamano, H.; Sugihara, K.; Nomura, K. Rapid poleward range expansion of tropical reef corals in response to rising sea surface temperatures. Geophys. Res. Lett. 2011, 38. [CrossRef]

7. Baird, A.H.; Sommer, B.; Madin, J.S. Pole-ward range expansion of Acropora spp. along the east coast of Australia. Coral Reefs 2012, 31, 1063. [CrossRef]

8. Nakamura, Y.; Feary, D.A.; Kanda, M.; Yamaoka, K. Tropical fishes dominate temperate reef fish communities within Western Japan. PLoS ONE 2013, 8, e81107. [CrossRef] [PubMed]

9. Scott, A.; Harasti, D.; Davis, T.; Smith, S.D. Southernmost records of the host sea anemone, Stichodactyla haddoni, and associated commensal shrimps in a climate change hotspot. Mar. Biodivers. 2014, 45, 1-2. [CrossRef]

10. Nimbs, M.J.; Willan, R.C.; Smith, S.D. Range extensions for heterobranch sea slugs (formerly opisthobranch) belonging to the families diaphanidae, Plakobranchidae and Facelinidae on the eastern coast of Australia. Mar. Biodivers. Rec. 2015, 8, e76. [CrossRef]

11. Przeslawski, R.; Ahyong, S.; Byrne, M.; Worheide, G.; Hutchings, P. Beyond coral and fish: The effects of climate change on non-coral benthic invertebrates of tropical reefs. Glob. Change Biol. 2008, 14, 2773-2795. [CrossRef]

12. Przeslawski, R.; Falkner, I.; Ashcroft, M.B.; Hutchings, P. Using rigorous selection criteria to investigate marine range shifts. Estuar. Coast. Shelf Sci. 2012, 113, 205-212. [CrossRef]

13. Poloczanska, E.S.; Babcock, R.C.; Butler, A.; Hobday, A.J.; Hoegh-Guldberg, O.; Kunz, T.J.; Matear, R.; Milton, D.A.; Okey, T.A.; Richardson, A.J. Climate change and Australian marine life. Oceanogr. Mar. Biol. 2007, 45, 407-478.

14. IPCC. Climate Change 2014: Synthesis Report. Contribution of Working Groups I, II and III to the Fifth Assessment Report of the Intergovernmental Panel on Climate Change; IPCC: Geneva, Switzerland, 2014.

15. Wernberg, T.; Russell, B.D.; Moore, P.J.; Ling, S.D.; Smale, D.A.; Campbell, A.; Coleman, M.A.; Steinberg, P.D.; Kendrick, G.A.; Connell, S.D. Impacts of climate change in a global hotspot for temperate marine biodiversity and ocean warming. J. Exp. Mar. Biol. Ecol. 2011, 400, 7-16. [CrossRef]

16. Cacciapaglia, C.; Woesik, R. Reef-coral refugia in a rapidly changing ocean. Glob. Change Biol. 2015, 21, 2272-2282. [CrossRef] [PubMed]

17. Waters, J.M.; Wernberg, T.; Connell, S.D.; Thomsen, M.S.; Zuccarello, G.C.; Kraft, G.T.; Sanderson, J.C.; West, J.A.; Gurgel, C.F.D. Australia's marine biogeography revisited: Back to the future? Aust. Ecol. 2010, 35, 988-992. [CrossRef]

18. Huber, M. Compendium of Bivalves. A Full Color Guide to 3300 of the World's Marine Bivalves. A Status on Bivalvia after 250 Years of Research; Conchbooks: Hackenheim, Geramny, 2010; Volume 1, p. 901.

19. Wilson, B.R.; Allen, G.R. Major components and distribution of marine fauna. In Fauna of Australia; Walton, G.R.D.D.W., Ed.; Australian Government Publishing Service: Canberra, Australia, 1987; Volume 1a, pp. 43-68.

20. Ponder, W.; Hutchings, P.; Chapman, R. Overview of the Conservation of Australian Marine Invertebrates; A Report for Environment Australia; Australian Museum: Sydney, Australia, 2002; p. 588.

21. Phillips, J.A. Marine macroalgal biodiversity hotspots: Why is there high species richness and endemism in southern Australian marine benthic flora? Biodivers. Conserv. 2001, 10, 1555-1577. [CrossRef]

22. Cork, S.; Sattler, P.; Alexandra, J. Biodiversity Theme Commentary Prepared for the 2006 Australian State of the Environment Committee. Available online: http://www.deh.gov.au/soe/2006/commentaries/ biodiversity/index.html (accessed on 12 September 2015).

23. Pearce, A.; Feng, M. Observations of warming on the Western Australian continental shelf. Mar. Freshw. Res. 2007, 58, 914-920. [CrossRef] 
24. Ling, S.D. Range expansion of a habitat-modifying species leads to loss of taxonomic diversity: A new and impoverished reef state. Oecologia 2008, 156, 883-894. [CrossRef] [PubMed]

25. Carpenter, R.C. Partitioning herbivory and its effects on coral-reef algal communities. Ecol. Monogr. 1986, 56, 345-364. [CrossRef]

26. Johnson, C.R.; Banks, S.C.; Barrett, N.S.; Cazassus, F.; Dunstan, P.K.; Edgar, G.J.; Frusher, S.D.; Gardner, C.; Haddon, M.; Helidoniotis, F.; et al. Climate change cascades: Shifts in oceanography, species' ranges and subtidal marine community dynamics in eastern tasmania. J. Exp. Mar. Biol. Ecol. 2011, 400, 17-32. [CrossRef]

27. Vergés, A.; Steinberg, P.D.; Hay, M.E.; Poore, A.G.B.; Campbell, A.H.; Ballesteros, E.; Heck, K.L.; Booth, D.J.; Coleman, M.A.; Feary, D.A.; et al. The tropicalization of temperate marine ecosystems: Climate-mediated changes in herbivory and community phase shifts. Proc. R. Soc. Lond. B Biol. Sci. 2014, 281, 20140846. [CrossRef] [PubMed]

28. Caputi, N.; Melville-Smith, R.; Lestang, S.D.; Pearce, A.; Feng, M. The effect of climate change on the Western rock lobster (Panulirus cygnus) fishery of Western Australia. Can. J. Fish. Aquat. Sci. 2010, 67, 85-96.

29. Stachowicz, J.J.; Terwin, J.R.; Whitlatch, R.B.; Osman, R.W. Linking climate change and biological invasions: Ocean warming facilitates nonindigenous species invasions. Proc. Natl. Acad. Sci. 2002, 99, 15497-15500. [CrossRef] [PubMed]

30. Thresher, R.; Proctor, C.; Ruiz, G.; Gurney, R.; MacKinnon, C.; Walton, W.; Rodriguez, L.; Bax, N. Invasion dynamics of the european shore crab, Carcinus maenas, in Australia. Mar. Biol. 2003, 142, 867-876.

31. Zeidberg, L.D.; Robison, B.H. Invasive range expansion by the Humboldt squid, Dosidicus gigas, in the eastern north pacific. Proc. Natl. Acad. Sci. 2007, 104, 12948-12950. [CrossRef] [PubMed]

32. Stewart, J.S.; Hazen, E.L.; Bograd, S.J.; Byrnes, J.E.K.; Foley, D.G.; Gilly, W.F.; Robison, B.H.; Field, J.C. Combined climate- and prey-mediated range expansion of Humboldt squid (Dosidicus gigas), a large marine predator in the california current system. Glob. Change Biol. 2014, 20, 1832-1843. [CrossRef] [PubMed]

33. Crain, C.M.; Kroeker, K.; Halpern, B.S. Interactive and cumulative effects of multiple human stressors in marine systems. Ecol. Lett. 2008, 11, 1304-1315. [CrossRef] [PubMed]

34. Halpern, B.S.; Walbridge, S.; Selkoe, K.A.; Kappel, C.V.; Micheli, F.; D’Agrosa, C.; Bruno, J.F.; Casey, K.S.; Ebert, C.; Fox, H.E.; et al. A global map of human impact on marine ecosystems. Science 2008, 319, 948-952. [CrossRef] [PubMed]

35. Greenstein, B.J.; Pandolfi, J.M. Escaping the heat: Range shifts of reef coral taxa in coastal Western Australia. Glob. Change Biol. 2008, 14, 513-528. [CrossRef]

36. Eliot, I.; Nutt, C.; Gozzard, B.; Higgins, M.; Buckley, E.; Bowyer, J. Coastal Compartments of Western Australia: A Physical Framework for Marine and Coastal Planning; Report to the Departments of Environment \& Conservation, Planning and Transport; Damara W.A. Pty Ltd, Geological Survey of Western Australia; Department of Environment \& Conservation: Western Australia, Australia, 2011.

37. Veron, J.E.N.; Marsh, L.M. Hermatypic corals of Western Australia. Records and annotated species list. Rec. West. Aust. Mus. Suppl. 1988, 29, 1-136.

38. Thomson, D.P.; Frisch, A.J. Extraordinarily high coral cover on a nearshore, high-latitude reef in south-west Australia. Coral Reefs 2010, 29, 923-927. [CrossRef]

39. Hutchins, J.B.; Pearce, A.F. Influence of the Leeuwin current on recruitment of tropical reef fishes at Rottnest Island, Western Australia. Bull. Mar. Sci. 1994, 54, 245-255.

40. Jones, D.S.; Morgan, G.J. An annotated checklist of the crustacea of Rottnest Island, Western Australia. In The Marine Flora and Fauna of Rottnest Island, Western Australia, Proceedings of the Fifth International Marine Biological Workshop, Rottnest Island, Australia, 5 January 1991; Wells, F.E., Walker, D.I., Kirkman, H., Lethbridge, R., Eds.; Western Australian Museum: Perth, Australia, 1993; Volume 1, pp. 135-162.

41. Huisman, J.M.; Walker, D.I. A catologue of the marine plants from Rottnest Island, Western Australia, with notes on their distribution and biogeography. Kingia 1990, 1, 365-481.

42. Wells, F.E., Walker, D.I., Kirkman, H., Lethbridge, R., Eds.; The Marine Flora and Fauna of Rottnest Island, Western Australia: Proceedings of the Fifth International Marine Biological Workshop, Rottnest Island, Australia; Western Australian Museum: Perth, Australia, 1993; Volume 1.

43. Wells, F.E., Walker, D.I., Kirkman, H., Lethbridge, R., Eds.; The Marine Flora and Fauna of Rottnest Island, Western Australia: Proceedings of the Fifth International Marine Biological Workshop, Rottnest Island, Australia; Western Australian Museum: Perth, Australia, 1993; Volume 2. 
44. Walker, D.I.; Wells, F.E. The Seagrass Flora and Fauna of Rottnest Island, Western Australia; Western Australian Museum: Perth, Australia, 1999; p. 421.

45. Farrant, P.A. Reproduction in the temperate Australian soft coral Capnella gaboensis. In Proceedings of the Fifth International Coral Reef Congress, Tahiti, 27 May-1 June 1985; Volume 4, pp. 319-324.

46. Verseveldt, J. Australian Octocorallia (Coelenterata). Aust. J. Mar. Freshw. Res. 1977, 28, 171-240. [CrossRef]

47. Alderslade, P. Four new genera of soft corals (coelenterata: Octocorallia), with notes on the classification of some established taxa. Zool. Meded. 2000, 74, 1-17.

48. Fromont, J.; Huggett, M.J.; Lengger, S.L.; Grice, K.; Schönberg, C.H. Characterisation of Leucetta prolifera, a calcarean cyanosponge from south-Western Australia, and its symbionts. J. Mar. Biol. Assoc. UK 2016, 96, 541-552. [CrossRef]

49. Hentschel, E. Tetraxonida. In Die Fauna Südwest-Australiens Ergebnisse der Hamburger Südwest-Australischen Forschungsreise, 1905; Michaelsen, W., Hartmeyer, R., Eds.; Fischer: Jena, Germany, 1909; Volume 2, pp. 347-402.

50. Morrison, H.; Wells, F.E. Colonisation of fremantle harbour and cockburn sound, Western Australia by the eastern Australian scallop Scaeochlamys livida (lamarck, 1819). Molluscan Res. 2008, 28, 107-110.

51. Knudsen, S.W.; Clements, K.D. Kyphosus gladius, a new species of sea chub from Western Australia (Teleostei: Kyphosidae), with comments on segutilum klunzingeri whitley. Zootaxa 2013, 3599, 1-18. [CrossRef] [PubMed]

52. Huisman, J.M. Marine Plants of Australia; University of Western Australia Press: Perth, Australia, $2000 ;$ p. 300.

53. Smale, D.A.; Wernberg, T. Extreme climatic event drives range contraction of a habitat-forming species. Proc. Biol. Sci. 2013, 280, 20122829. [CrossRef] [PubMed]

54. Huisman, J.M. The type and Australian species of the red algal genera liagora and ganonema (Liagoraceae, Nemaliales). Aust. Syst. Bot. 2002, 15, 773-838. [CrossRef]

55. Lin, S.-M.; Yang, S.-Y.; Huisman, J.M. Systematic revision of the genera Liagora and Izziella (Liagoraceae, Rhodophyta) from Taiwan based on lsu and rbcl sequencing analyses and carposporophyte development with description of I. hommersandii sp. nov. and I. kuroshioensis sp. nov. J. Phycol. 2011, 47, 352-365. [CrossRef]

56. Huisman, J.M. Algae of Australia: Nemaliales; ABRS: Canberra, Australia, 2006.

57. Hutchings, P.A.; Ahyong, S.T.; Ashcroft, M.B.; McGrouther, M.A.; Reid, A.L. Sydney harbour: Its diverse biodiversity. Aust. Zool. 2013, 36, 255-320. [CrossRef]

58. Jones, D.S. The barnacles of Rottnest Island, Western Australia, with descriptions of two new species. In The Marine Flora and Fauna of Rottnest Island, Western Australia, Proceedings of the Fifth International Marine Biological Workshop, Rottnest Island, Australia, 5 January 1991; Wells, F.E., Walker, D.I., Kirkman, H., Lethbridge, R., Eds.; Western Australian Museum: Perth, Australia, 1993; Volume 1, pp. 105-133.

59. Gales, C.F. Mr c.F. Gales report. Western Mail, 1907, 60.

60. Fromont, J. Reproduction of some demosponges in a temperate Australian shallow water habitat. Mem. Qld. Mus. 1999, 44, 185-192.

61. Sampey, A.; Fromont, J.; Johnston, D.J. Demersal and epibenthic fauna in a temperate marine embayment, Cockburn Sound, Western Australia: Determination of key indicator species. J. Roy. Soc. West. Aust. 2011, 94, 1-18.

62. Hall-Spencer, J.M.; Allen, R. The impact of $\mathrm{CO}_{2}$ emissions on "nuisance" marine species. Res. Rep. Biodivers. Stud. 2015, 33, 33-46. [CrossRef]

63. Feng, M.; Caputi, N.; Pearce, A. Leeuwin current. In In a Marine Climate Change Impacts and Adaptation Report Card for Australia 2012; Poloczanska, E.S., Hobday, A.J., Richardson, A.J., Eds.; CSIRO Marine and Atmospheric Research: Brisbane, Australia, 2012; pp. 61-80.

64. Hutchins, J.B. Dispersal of tropical fishes to temperate seas in the southern hemisphere. J. R. Soc. West. Aust. 1991, 74, 79-84.

65. Cure, K.; Hobbs, J.-P.A.; Harvey, E.S. High recruitment associated with increased sea temperatures towards the southern range edge of a Western Australian endemic reef fish Choerodon rubescens (family Labridae). Environ. Biol. Fish. 2014, 98, 1059-1067. [CrossRef]

66. Pearce, A.F.; Hutchins, J.B. Record-Breaking Temperatures and Tropical Fish Recruitment at Rottnest Island; Fisheries Research Report [Western Australia]; IMAS: Perth, Australia, 2014; pp. 25-26.

67. Wernberg, T.; Smale, D.A.; Tuya, F.; Thomsen, M.S.; Langlois, T.J.; de Bettignies, T.; Bennett, S.; Rousseaux, C.S. An extreme climatic event alters marine ecosystem structure in a global biodiversity hotspot. Nat. Clim. Change 2013, 3, 78-82. [CrossRef] 
68. Bennett, S.; Wernberg, T.; Harvey, E.S.; Santana-Garcon, J.; Saunders, B.J. Tropical herbivores provide resilience to a climate-mediated phase shift on temperate reefs. Ecol. Lett. 2015, 18, 677-686. [CrossRef] [PubMed]

69. Thomson, D.P.; Bearham, D.; Graham, F.; Eagle, J.V. High latitude, deeper water coral bleaching at Rottnest Island, Western Australia. Coral Reefs 2011, 30, 1107. [CrossRef]

70. Moore, J.A.; Bellchambers, L.M.; Depczynski, M.R.; Evans, R.D.; Evans, S.N.; Field, S.N.; Friedman, K.J.; Gilmour, J.P.; Holmes, T.H.; Middlebrook, R.; et al. Unprecedented mass bleaching and loss of coral across 12 of latitude in Western Australia in 2010-2011. PLoS ONE 2012, 7, e51807. [CrossRef] [PubMed]

71. Feng, M.; Pearce, A.F. The rise and fall of the "marine heat wave" off Western Australia during the summer of 2010/2011. J. Mar. Syst. 2013, 111-112, 139-156.

72. Bennett, S.; Wernberg, T.; Connell, S.D.; Hobday, A.J.; Johnson, C.R.; Poloczanska, E.S. The "Great Southern Reef": Social, ecological and economic value of Australia's neglected kelp forests. Mar. Freshw. Res. 2015, 67, 47-56. [CrossRef]

(C) 2016 by the authors; licensee MDPI, Basel, Switzerland. This article is an open access article distributed under the terms and conditions of the Creative Commons by Attribution (CC-BY) license (http:/ / creativecommons.org/licenses/by/4.0/). 